\title{
Article \\ Nickel-Based Metal-Organic Frameworks as Electrocatalysts for the Oxygen Evolution Reaction (OER)
}

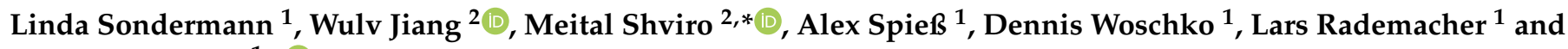 \\ Christoph Janiak ${ }^{1, *}$ (D) \\ 1 Institut für Anorganische Chemie und Strukturchemie, Heinrich-Heine-Universität Düsseldorf, \\ 40225 Düsseldorf, Germany; linda.sondermann@hhu.de (L.S.); alex.spiess@hhu.de (A.S.); \\ dennis.woschko@hhu.de (D.W.); lars.rademacher@hhu.de (L.R.) \\ 2 Forschungszentrum Jülich $\mathrm{GmbH}$, Institute of Energy and Climate Research, IEK-14: Electrochemical Process \\ Engineering, 52425 Jülich, Germany; j.wulv@fz-juelich.de \\ * Correspondence: m.shviro@fz-juelich.de (M.S.); janiak@uni-duesseldorf.de (C.J.); Tel.: +49-211-81-12286 (C.J.)
}

check for

updates

Citation: Sondermann, L.; Jiang, W.; Shviro, M.; Spieß, A.; Woschko, D.; Rademacher, L.; Janiak, C. Nickel-Based Metal-Organic Frameworks as Electrocatalysts for the Oxygen Evolution Reaction (OER). Molecules 2022, 27, 1241. https://doi.org/10.3390/ molecules27041241

Academic Editors: Jingqi Guan and Yin Wang

Received: 21 January 2022 Accepted: 6 February 2022 Published: 12 February 2022

Publisher's Note: MDPI stays neutral with regard to jurisdictional claims in published maps and institutional affiliations.

Copyright: (c) 2022 by the authors. Licensee MDPI, Basel, Switzerland. This article is an open access article distributed under the terms and conditions of the Creative Commons Attribution (CC BY) license (https:// creativecommons.org/licenses/by/ $4.0 /)$.

\begin{abstract}
The exploration of earth-abundant electrocatalysts with high performance for the oxygen evolution reaction (OER) is eminently desirable and remains a significant challenge. The composite of the metal-organic framework (MOF) $\mathrm{Ni}_{10} \mathrm{Co}-\mathrm{BTC}$ (BTC = 1,3,5-benzenetricarboxylate) and the highly conductive carbon material ketjenblack $(\mathrm{KB})$ could be easily obtained from the MOF synthesis in the presence of $\mathrm{KB}$ in a one-step solvothermal reaction. The composite and the pristine MOF perform better than commercially available $\mathrm{Ni} / \mathrm{NiO}$ nanoparticles under the same conditions for the OER. Activation of the nickel-cobalt clusters from the MOF can be seen under the applied anodic potential, which steadily boosts the OER performance. $\mathrm{Ni}_{10} \mathrm{Co}-\mathrm{BTC}$ and $\mathrm{Ni}_{10} \mathrm{Co}-\mathrm{BTC} / \mathrm{KB}$ are used as sacrificial agents and undergo structural changes during electrochemical measurements, the stabilized materials show good OER performances.
\end{abstract}

Keywords: metal-organic frameworks (MOF); electrocatalysis; oxygen evolution reaction (OER); nickel; ketjenblack

\section{Introduction}

The depletion of fossil fuels and their direct correlation in increasing global greenhouse gas emissions through their combustion show that the development of new sustainable clean energy sources is required [1-3]. A possible solution is coupling renewable energy sources like solar and wind energy with electrochemical water splitting to convert surplus electrical energy into storable hydrogen fuel [4-7]. Electrochemical water splitting consists of two half reactions, the cathodic hydrogen evolution reaction (HER; alkaline conditions: $4 \mathrm{H}_{2} \mathrm{O}+4 \mathrm{e}^{-} \rightarrow 2 \mathrm{H}_{2}+4 \mathrm{OH}^{-}, \mathrm{E}^{\circ}=0.00 \mathrm{~V}$ vs. $\left.\mathrm{RHE}\right)$ and the anodic oxygen evolution reaction (OER, alkaline conditions: $4 \mathrm{OH}^{-} \rightarrow \mathrm{O}_{2}+4 \mathrm{e}^{-}+2 \mathrm{H}_{2} \mathrm{O}, \mathrm{E}^{\circ}=1.23 \mathrm{~V}$ vs. $\left.\mathrm{RHE}\right)[8,9]$. The OER involves a four electron-proton coupled transfer process to generate one oxygen molecule and occurs at an applied potential (overpotential $\eta$ ) much higher than the theoretical equilibrium potential of $\mathrm{E}^{\circ}=1.23 \mathrm{~V}$ vs. RHE [8,10-14]. The overpotential is the difference between the applied potential and the equilibrium potential

$$
\eta_{\mathrm{OER}}=\mathrm{E}_{\mathrm{RHE}}-\mathrm{E}^{\circ}(1.23 \mathrm{~V})
$$

and it is one of the key parameters on which the performance of an electrocatalyst is evaluated on $[9,15,16]$. Ideally a highly active electrocatalyst produces a large current density with a small overpotential [11] together with long-term stability. Another key parameter, which gives insight into the reaction mechanism and rate-determining step, is the Tafel slope (b), which can be obtained through the Tafel-equation $[12,17,18]$.

$$
\eta=a+b \times \log (j)
$$


Up to date electrocatalysts based on noble metals, such as ruthenium and iridium, together with their oxides $\mathrm{RuO}_{2}$ and $\mathrm{IrO}_{2}$, are the OER-catalysts with the best performance, independently of the $\mathrm{pH}$ of the electrolyte [19-21]. However, the scarcity and high costs of these noble metals severely hinder a large-scale industrial application. Subsequent research has been directed towards the development of non-noble metal alternatives for the OER [22,23]. Research focuses on finding active, stable and inexpensive electrocatalysts, where especially 3d-transition-metals such as $\mathrm{Fe}, \mathrm{Ni}$ and $\mathrm{Co}$ are of high interest $[7,24,25]$. Recently metal-organic frameworks (MOFs) and MOF-based electrocatalysts have been paid much attention [26,27]. MOFs are potentially porous, crystalline coordination networks with metal nodes and bridging organic ligands [28,29]. MOFs have been investigated as electrocatalysts due to their high porosity, large surface areas, diversity of composition and structure [27,30-33]. MOFs can be used directly for electrocatalytic reactions, but they have drawbacks like (i) low electrical conductivity, (ii) mass transport problems of reactants, products and electrolyte ions through their micropores, (iii) lack of stability especially in highly acidic or alkaline aqueous environments [34]. Because of those drawbacks, MOFs are often employed as precursors or sacrificial agents to construct structured carbon-based metal oxide materials as efficient electrocatalysts $[27,32,35]$. To increase the low electric conductivity and the electrocatalytic performance of MOFs carbon supports are added such as graphene [36], carbon nanotubes (CNTs) [21] or ketjenblack (KB) [37]. The performance of Ni-MOF electrocatalysts could be enhanced by the introduction of a second metal such as cobalt or iron [35,38-41]. Our previous work has shown that a $\mathrm{Ni}(\mathrm{Fe})-\mathrm{MOF} / \mathrm{KB}$ composite exhibited remarkable OER performance [34]. The MOF Ni-BTC and $\mathrm{Ni}(\mathrm{Fe})-\mathrm{BTC}$ (BTC $=1,3,5$-benzenetricarboxylate) have a fast charge transfer rate and high activity for the OER [40,42]. A mixed-metal Ni(Co)-BTC MOF has only been used as a sacrificial agent to give $\mathrm{NiCo}_{2} \mathrm{O}_{4}$ [35], which encouraged us to take a closer look at the activity of the pristine $\mathrm{MOF}$ and the composite material including KB for the OER in this work.

\section{Results and Discussion}

\subsection{Synthesis and Characterization of the Ni-BTC Analogs}

The Ni-BTC structure is identical to the Cu-BTC or HKUST-1 structure (HKUST = Hong Kong University of Science and Technology) [43] both are built by dinuclear metal(II)secondary building units (SBUs), which are connected by BTC in a paddle-wheel fashion to a three-dimensional network of formula $\left[\mathrm{Ni}_{3}(\mathrm{BTC})_{2}\right][43,44]$. The composite of $\mathrm{Ni}_{10} \mathrm{Co}$ BTC and $\mathrm{KB}$, named $\mathrm{Ni}_{10} \mathrm{Co}-\mathrm{BTC} / \mathrm{KB}$ was generated through a facile MOF synthesis in the presence of ketjenblack $(\mathrm{KB})$ in a one-step solvothermal reaction at $170{ }^{\circ} \mathrm{C}$ for $48 \mathrm{~h}$ from a mixture of $\mathrm{Ni}\left(\mathrm{NO}_{3}\right)_{2} .6 \mathrm{H}_{2} \mathrm{O}, \mathrm{Co}\left(\mathrm{NO}_{3}\right)_{2} .6 \mathrm{H}_{2} \mathrm{O}$ (molar Ni:Co ratio 10:1), 1,3,5-benzenetricarboxylic acid ( $\left.\mathrm{H}_{3} \mathrm{BTC}\right)$, 2-methylimidazole (2-MeImH), and $\mathrm{KB}$ in N,Ndimethylformamide (DMF) (Figure 1). $\mathrm{Ni}_{10} \mathrm{Co}-\mathrm{BTC}$ and $\mathrm{Ni}_{10} \mathrm{Fe}-\mathrm{BTC}$ were synthesized for comparison. Ni-BTC and the mixed-metal analogs are obtained as the dimethylamine adduct $\left[\mathrm{Ni}_{3}(\mathrm{BTC})_{2}\left(\mathrm{Me}_{2} \mathrm{NH}\right)_{3}\right]$ at the axial metal position with $\mathrm{Me}_{2} \mathrm{NH}$ being a hydrolysis product of DMF [43] (from the CHN elemental analysis data in Table S1, Supporting Information (SI)). 


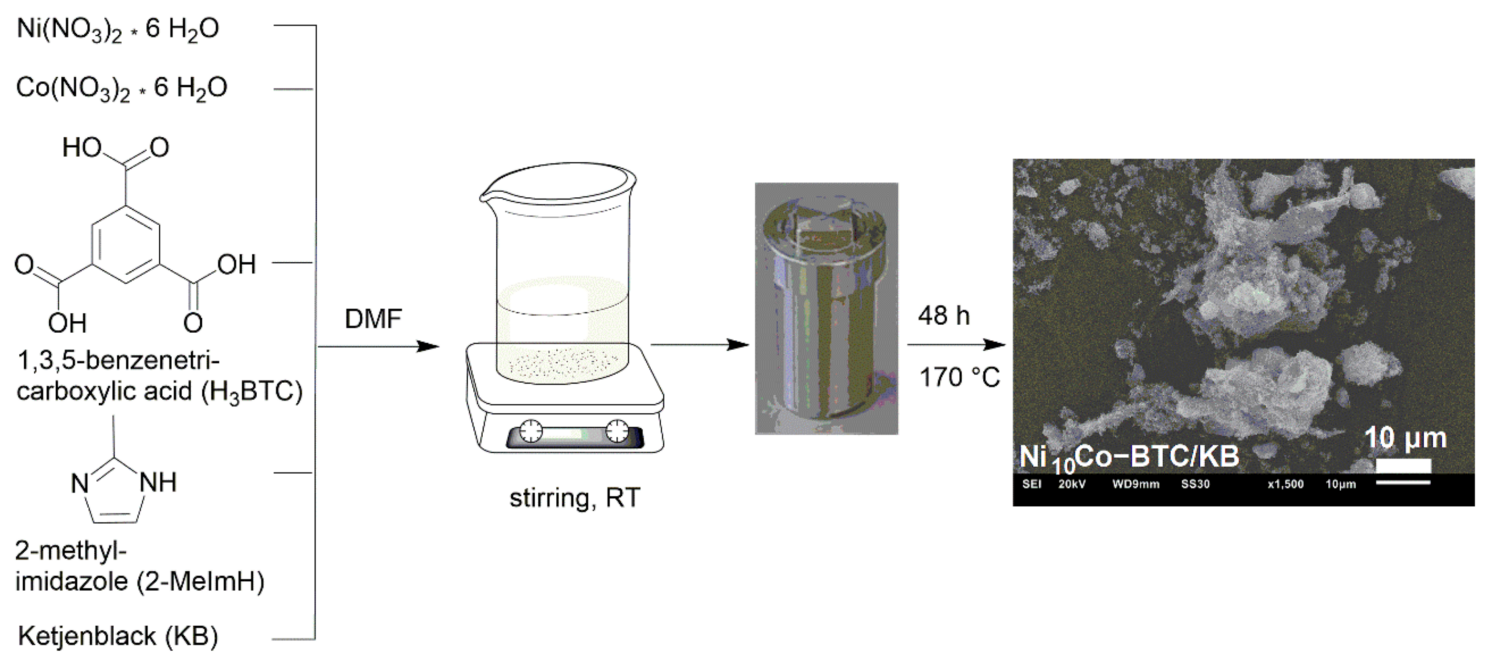

Figure 1. Schematic illustration of the $\mathrm{Ni}_{10} \mathrm{Co}-\mathrm{BTC} / \mathrm{KB}$ composite synthesis.

A well-known phenomenon in mixed-metal MOF synthesis is that the incorporated metal ratio can differ from the starting material ratio and must be post-synthetically quantified. To quantify the amount of $\mathrm{Co}$ and $\mathrm{Fe}$ in the synthesized $\mathrm{Ni}_{10} \mathrm{Co}-\mathrm{BTC}$ and $\mathrm{Ni}_{10} \mathrm{Fe}_{\mathrm{BTC}}$ flame atomic absorption spectroscopy (AAS) was conducted post-synthetically, resulting in a molar $\mathrm{Ni}$ :Co ratio of $11: 1$ for $\mathrm{Ni}_{10} \mathrm{Co}-\mathrm{BTC}$ and a molar $\mathrm{Ni}$ :Fe ratio of $11: 1$ for $\mathrm{Ni}_{10} \mathrm{Fe}-\mathrm{BTC}$ (Table 1).

Table 1. SEM-EDX and AAS results of the mixed-metal samples.

\begin{tabular}{ccccccc}
\hline Sample & \multicolumn{2}{c}{ SEM-EDX } & \multicolumn{3}{c}{ AAS * } \\
& \multicolumn{2}{c}{ Molar Ratio } & \multicolumn{2}{c}{ Metal wt.\% } & Approximate Molar Ratio \\
\cline { 2 - 7 } & $\mathbf{N i}$ & $\mathbf{F e} / \mathbf{C o}$ & $\mathbf{N i}$ & $\mathbf{F e} / \mathbf{C o}$ & $\mathbf{N i}$ & Fe/Co \\
\hline $\mathrm{Ni}_{10} \mathrm{Fe}-\mathrm{BTC}$ & 9 & 1 & 16.7 & 1.5 & 11 & 1 \\
$\mathrm{Ni}_{10}$ Co-BTC & 7 & 1 & 16.3 & 1.5 & 11 & 1 \\
$\mathrm{Ni}_{10} \mathrm{Co}-\mathrm{BTC} / \mathrm{KB}$ & 7 & 1 & 10.6 & 1.3 & 8 & 1
\end{tabular}

* Atomic absorption spectroscopy. Weighted samples were heated to dryness with aqua regia for two times and afterwards stirred with aqua regia overnight. The solution was carefully filtered and diluted with Millipore water to a volume of $25 \mathrm{~mL}$. The resulting solutions were further diluted with Millipore water (1:50) for the AAS measurements.

From the AAS determined metal wt.\%, the mass fractions of the MOF in the KB composites were calculated as $67 \mathrm{wt} . \% \mathrm{Ni}_{10} \mathrm{Co}-\mathrm{BTC}$ together with $33 \mathrm{wt} . \% \mathrm{~KB}$.

Powder X-ray diffraction (PXRD) patterns of $\mathrm{Ni}_{10} \mathrm{Fe}-\mathrm{BTC}, \mathrm{Ni}_{10} \mathrm{Co}-\mathrm{BTC}, \mathrm{Ni}_{10} \mathrm{Co}-\mathrm{BTC} / \mathrm{KB}$, $\mathrm{KB}$ and a simulated diffraction pattern of Ni-BTC are illustrated in Figure 2a. The pristine MOF samples $\mathrm{Ni}_{10} \mathrm{Fe}-\mathrm{BTC}$ and $\mathrm{Ni}_{10} \mathrm{Co}-\mathrm{BTC}$ exhibit the same reflexes as the simulated pattern of Ni-BTC. The composite $\mathrm{Ni}_{10} \mathrm{Co}-\mathrm{BTC} / \mathrm{KB}$ also demonstrated a PXRD pattern, which agrees to the simulated pattern of $\mathrm{Ni}-\mathrm{BTC}$ and also the pristine $\mathrm{MOF} \mathrm{Ni}_{10} \mathrm{Co}-\mathrm{BTC}$. The aforementioned PXRD patterns show that the addition of amorphous $\mathrm{KB}$ in the synthesis did not influence the MOF crystal growth and structure significantly [45,46]. Apart from the reflexes of the simulated Ni-BTC MOF there are no additional reflexes in the diffraction patterns of the samples, which reveals that no iron or cobalt(oxy)hydroxides formed in the synthesis. This indicates that the second metal (iron or cobalt) was well incorporated into the structure of the Ni-BTC MOF. Pure KB displayed three broad diffraction peaks corresponding to the (100), (002), (101) planes of amorphous carbon [47,48]. 


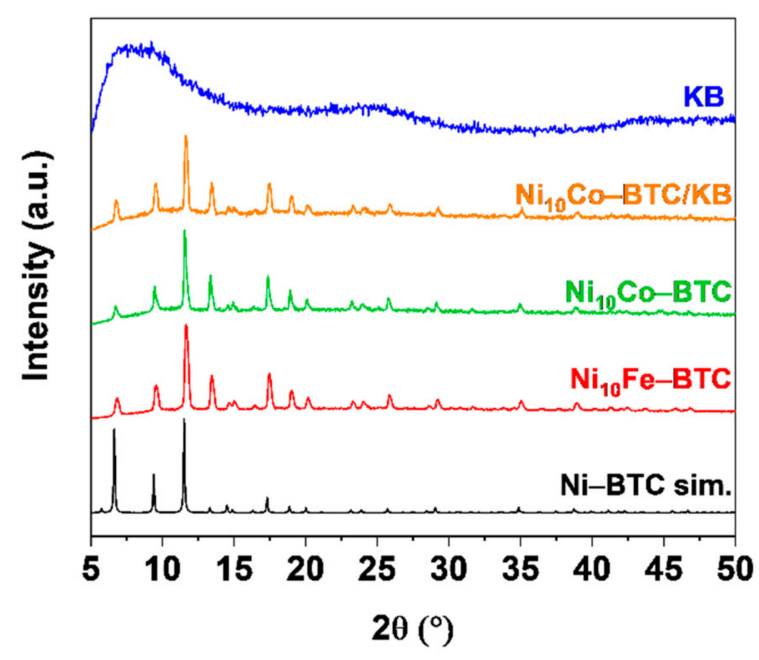

(a)

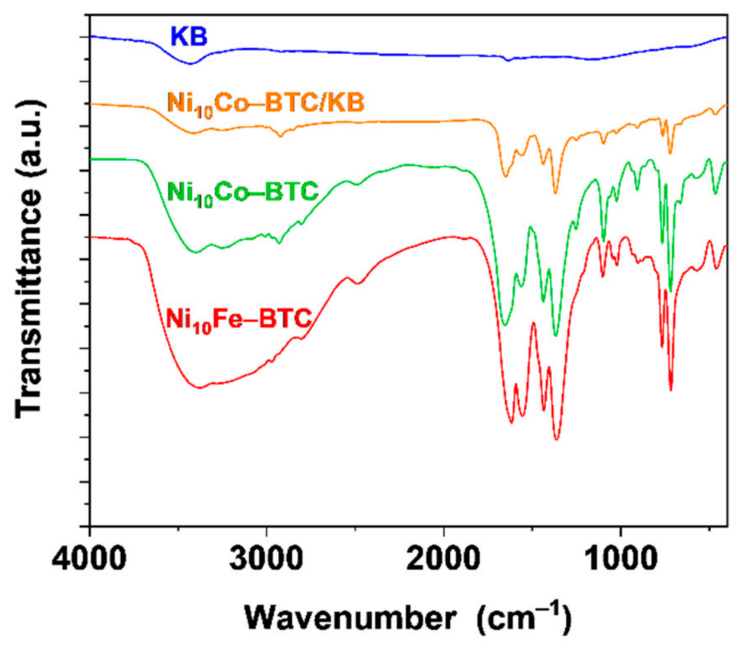

(b)

Figure 2. (a) PXRD patterns of experimental $\mathrm{Ni}_{10} \mathrm{Fe}-\mathrm{BTC}$ (red), $\mathrm{Ni}_{10} \mathrm{Co}-\mathrm{BTC}$ (green), $\mathrm{Ni}_{10} \mathrm{Co}-\mathrm{BTC} / \mathrm{KB}$ (orange), KB (blue) and simulated Ni-BTC (black) (CCDC Nr. 802889); (b) FT-IR spectra of $\mathrm{Ni}_{10} \mathrm{Fe}_{-\mathrm{BTC}}$ (red), $\mathrm{Ni}_{10} \mathrm{Co}-\mathrm{BTC}$ (green), $\mathrm{Ni}_{10} \mathrm{Co}-\mathrm{BTC} / \mathrm{KB}$ (orange) and $\mathrm{KB}$ (blue).

Fourier transform infrared (FT-IR) spectra (Figure 2b) of the Ni-BTC analogs demonstrate the same characteristic bands (listed in Table S2, SI) which are in a good agreement with the literature [39]. A broad band in the region of $3600-3000 \mathrm{~cm}^{-1}$ and a band around $1650 \mathrm{~cm}^{-1}$ can be attributed to the stretching and bending vibrations of -OH group from adsorbed or coordinated water [43,49-51]. Characteristic vibrations of a Ni-O bond 577$460 \mathrm{~cm}^{-1}$ [51] and of carboxylate-groups 1617-1556 $\mathrm{cm}^{-1}$ (asymmetric vibration) and $1439-1364 \mathrm{~cm}^{-1}$ (symmetric vibration) can be observed in all samples [50,52]. Vibrations of a Fe-O bond are reported at 538 and $634 \mathrm{~cm}^{-1}$ and of a $\mathrm{Fe}_{2} \mathrm{Ni}-\mathrm{O}$ bond at ca. $720 \mathrm{~cm}^{-1}$, which is also in the range of the vibration of a Co-O bond $\left(725 \mathrm{~cm}^{-1}\right)$ [53-55]. Fe-O could not be detected and the $\mathrm{Fe}_{2} \mathrm{Ni}-\mathrm{O}$ and $\mathrm{Co}-\mathrm{O}$ bonds are all in a similar range to each other and to aromatic vibrations (Table S2, SI).

The specific Brunauer-Emmett-Teller (BET) surface areas and pore volumes of the materials were derived from nitrogen-adsorption isotherms at $77 \mathrm{~K}$ (Figure $3 \mathrm{a}$ ) and are given in Table S3, SI.

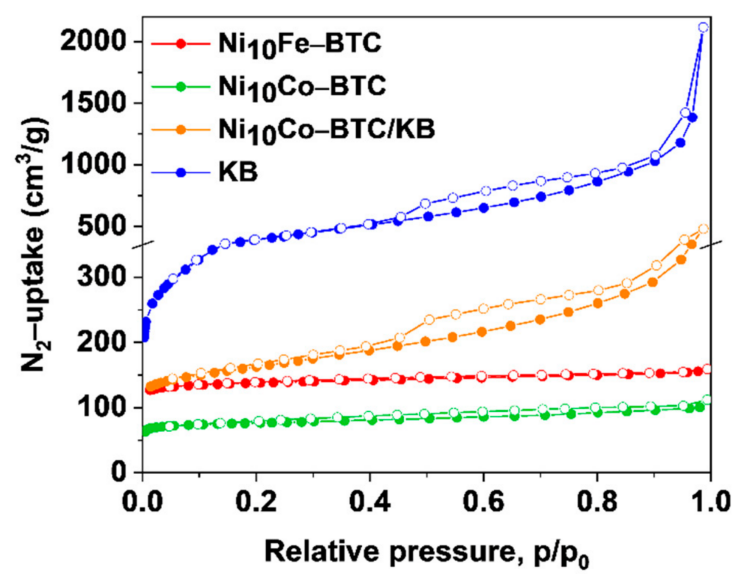

(a)

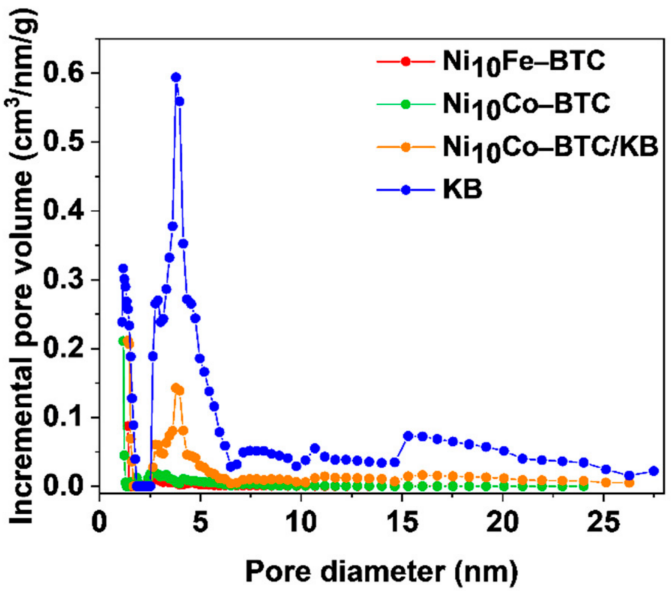

(b)

Figure 3. (a) $\mathrm{N}_{2}$-sorption isotherms at $77 \mathrm{~K}$ (Adsorption: filled circles; desorption: empty circles), (b) pore size distributions of $\mathrm{Ni}_{10} \mathrm{Fe}-\mathrm{BTC}$ (red), $\mathrm{Ni}_{10} \mathrm{Co}-\mathrm{BTC}$ (green), $\mathrm{Ni}_{10} \mathrm{Co}-\mathrm{BTC} / \mathrm{KB}$ (orange) and KB (blue). 
The BET surface areas of the Ni-BTC analogs ( $\mathrm{Ni}_{10} \mathrm{Fe}-\mathrm{BTC}: 555 \mathrm{~m}^{2} / \mathrm{g}, \mathrm{Ni}_{10} \mathrm{Co}-\mathrm{BTC}$ : $303 \mathrm{~m}^{2} / \mathrm{g}$ and $\mathrm{Ni}_{10} \mathrm{Co}-\mathrm{BTC} / \mathrm{KB}: 596 \mathrm{~m}^{2} / \mathrm{g}$ ) are all in the range of reported values for neat

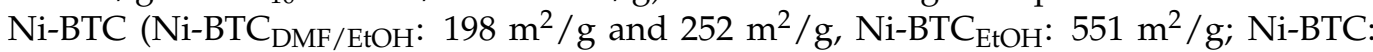
$0.286 \mathrm{~cm}^{3} / \mathrm{g}$ ) $[56,57]$. $\mathrm{Ni}_{10} \mathrm{Fe}-\mathrm{BTC}$ and $\mathrm{Ni}_{10} \mathrm{Co}-\mathrm{BTC}$ show a type I isotherm revealing their microporosity with a steep gas uptake at low relative pressure followed by a plateau [58-60]. $\mathrm{KB}$ is a porous carbon material with a BET surface area of $1415 \mathrm{~m}^{2} / \mathrm{g}$, a pore volume of $1.59 \mathrm{~cm}^{3} / \mathrm{g}$ (Table S3, SI) and mesopores, which are mostly around $4 \pm 2 \mathrm{~nm}$ (Figure $3 \mathrm{~b}$ ). The adsorption isotherm branch of $\mathrm{KB}$ is a composite of a type I and II isotherm and the desorption isotherm branch additionally displays a $\mathrm{H} 4$ hysteresis, both being often indicators for micro-mesoporous carbons [58]. The nitrogen sorption isotherm and BETsurface area of the composite $\mathrm{Ni}_{10} \mathrm{Co}-\mathrm{BTC} / \mathrm{KB}$ is a superposition of the isotherms of the MOF and KB components (Figure 3a). This superposition also holds for the pore-size distribution of the individual components in the composite (Figure 3b). The bimodal pore size distribution of $\mathrm{Ni}_{10} \mathrm{Co}-\mathrm{BTC} / \mathrm{KB}$ with maxima at $\sim 2 \mathrm{~nm}$ and $\sim 4 \mathrm{~nm}$ reflects the contributions from the MOF and KB. Consequently, the BET surface area and pore volume of the $\mathrm{Ni}_{10} \mathrm{Co}-\mathrm{BTC} / \mathrm{KB}$ composite with $596 \mathrm{~m}^{2} / \mathrm{g}$ and $0.45 \mathrm{~cm}^{3} / \mathrm{g}$, respectively, are higher than the surface area and pore volume of neat $\mathrm{Ni}_{10}$ Co-BTC $\left(303 \mathrm{~m}^{2} / \mathrm{g}, 0.15 \mathrm{~cm}^{3} / \mathrm{g}\right)$ but still lower than the calculated BET surface area $\left(670 \mathrm{~m}^{2} / \mathrm{g}\right)$ as determined from the sum of the mass-weighted S(BET) of KB (33 wt.\%) and MOF (67 wt.\%) (Equation (3) [34]):

$$
\mathrm{S}(\mathrm{BET})_{\text {calc. }}=\frac{\text { wt. } \% \text { of } \mathrm{KB}}{100} \times \mathrm{S}(\mathrm{BET})_{\mathrm{KB}}+\frac{\text { wt. } \% \text { of } \mathrm{MOF}}{100} \times \mathrm{S}(\mathrm{BET})_{\mathrm{MOF}}
$$

The slightly lower BET surface area can be due to pore blocking effects or formation of the MOF in the mesopores of $\mathrm{KB}$, as evidenced by the large reduction of the incremental mesopore volume in Figure $3 b$.

Thermogravimetric analyses (TGA) under $\mathrm{N}_{2}$ atmosphere yield a similar curvature for all Ni-BTC analogs (Figure S1, SI). In the range of $30-320^{\circ} \mathrm{C}$ the initial weight losses until decomposition can be attributed to the loss of crystal solvent molecules $\left(\mathrm{DMF}, \mathrm{H}_{2} \mathrm{O}\right)$ incorporated in the cavities [61]. After complete solvent loss the BTC-linker together with the MOF structure decomposes around 350-600 ${ }^{\circ} \mathrm{C}$ (Lit. 337-450 ${ }^{\circ} \mathrm{C}$ ) (mass change of $54-57 \%$, Figure S1, SI) $[56,60]$. The TGA curves are in agreement with reported curves for NiCo-BTC and Ni-BTC [35,43,60,61].

Scanning electron microscopy (SEM) images of $\mathrm{Ni}_{10} \mathrm{Fe}-\mathrm{BTC}$ (Figure $4 \mathrm{a}$ ) present spherical and cubic particles, which is in accordance with the literature [40]. $\mathrm{Ni}_{10} \mathrm{Co}-\mathrm{BTC}$ (Figure 4b) has irregular shaped aggregates similar to reported Ni-BTC [40]. The KB particles (Figure S3, SI) are smaller than the MOF particles, and do not have a clearly defined shape. In the composite material $\mathrm{Ni}_{10} \mathrm{Co}-\mathrm{BTC} / \mathrm{KB}$ (Figure $4 \mathrm{c}$ ) the MOF particles are covered by KB. SEM-energy-dispersive X-ray spectroscopy (EDX) was conducted for the mixedmetal MOFs (Figure 4 and Figure S2, SI) and KB (Figure S3, SI). For the mixed-metal MOFs SEM-EDX metal element mapping (Figure 4) reveals a good superposition of the two different metals. It is evident that the mapping of nickel and iron or cobalt of $\mathrm{Ni}_{10} \mathrm{Fe}-\mathrm{BTC}$ and $\mathrm{Ni}_{10} \mathrm{Co}-\mathrm{BTC}$, respectively, is more visible than for $\mathrm{Ni}_{10} \mathrm{Co}-\mathrm{BTC} / \mathrm{KB}$, where the $\mathrm{KB}$ partially covers and masks surface of the MOF particles. 

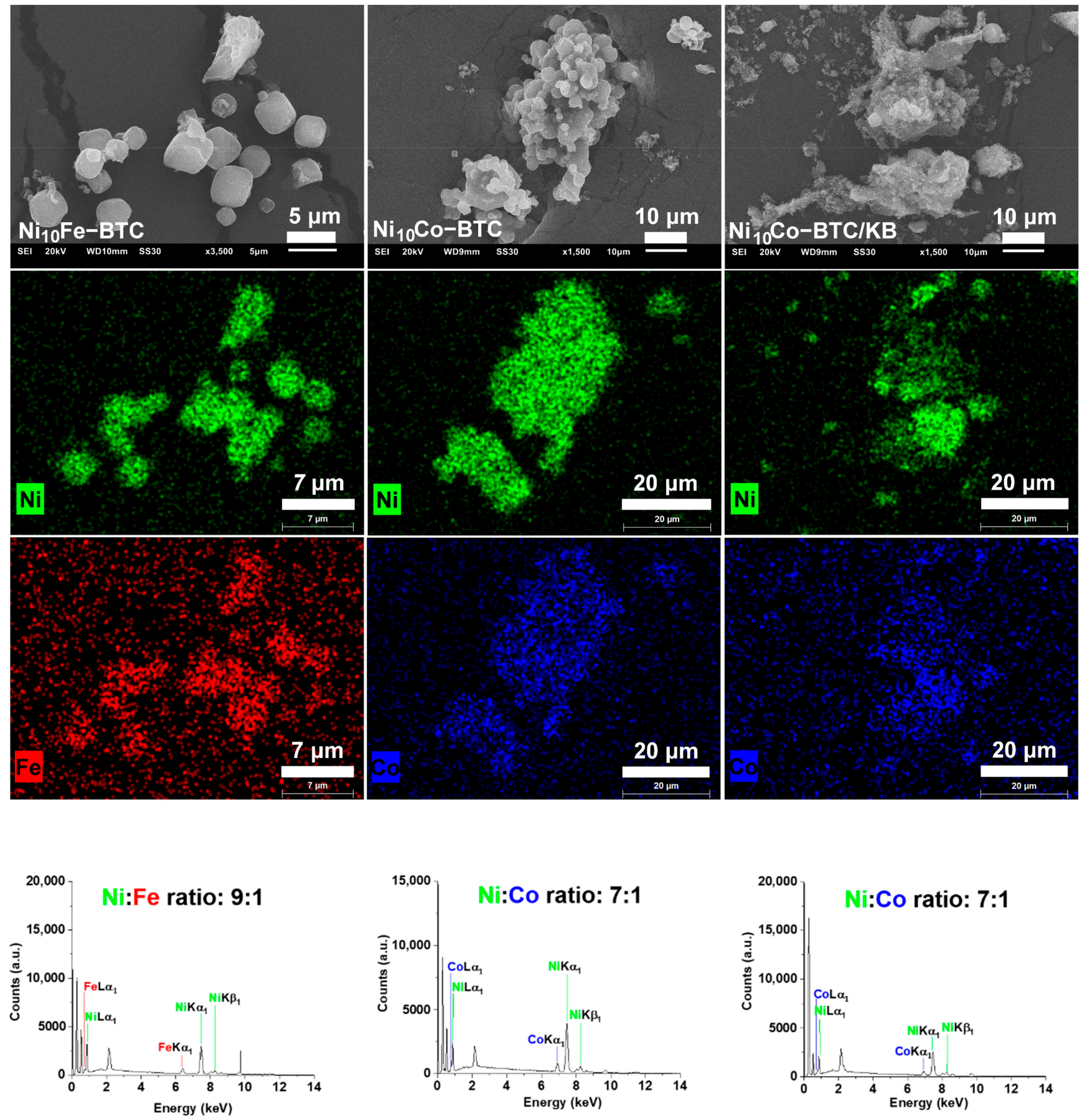

(a)

(b)

(c)

Figure 4. SEM images (top row), SEM-EDX metal element mappings (two middle rows) and EDX spectra (bottom row) for (a) $\mathrm{Ni}_{10} \mathrm{Fe}-\mathrm{BTC}$, (b) $\mathrm{Ni}_{10} \mathrm{Co}-\mathrm{BTC}$ and (c) $\mathrm{Ni}_{10} \mathrm{Co}-\mathrm{BTC} / \mathrm{KB}$.

The metal contents of the mixed-metal samples were quantified by SEM-EDX and atomic absorption spectroscopy (AAS) and are compared in Table 1. The SEM-EDX results are more indicative of the metal ratio of the surface of the samples and the AAS results quantify the metal ratio of the bulk samples. For the synthesis of all materials a starting molar ratio of 10:1 was used for nickel to iron or cobalt. $\mathrm{Ni}_{10} \mathrm{Fe}-\mathrm{BTC}$ and $\mathrm{Ni}_{10} \mathrm{Co}-\mathrm{BTC}$ give similar AAS results with a ratio of approximately 11:1 (Ni:Fe/Co), which is close to the 
used 10:1 molar ratio for the synthesis. The AAS of the composite material $\mathrm{Ni}_{10} \mathrm{Co}-\mathrm{BTC} / \mathrm{KB}$ results in a Ni:Co ratio of approximately $8: 1$, which is a little lower than the implemented molar ratio in the beginning.

\subsection{Electrocatalytical Results}

The OER performance of all samples was checked using a three-electrode system with rotation disk electrode in $1 \mathrm{~mol} / \mathrm{L} \mathrm{KOH}$ electrolyte. The electrochemical kinetics of the samples were evaluated by comparison of the Tafel slopes derived from linear sweep voltammetry (LSV) curves after the activation. Apart from the overpotential and Tafel slope the stability of the electrocatalysts were examined by comparing the overpotential before and after 1000 cyclic voltammetry cycles (CVs). Details are given in the experimental section.

The LSV curves in Figure $5 \mathrm{a}, \mathrm{b}$ show that $\mathrm{Ni}_{10} \mathrm{Fe}-\mathrm{BTC}$ reaches the highest current density before the stability test in comparison to the reference commercial $\mathrm{Ni} / \mathrm{NiO}$ nanoparticles, $\mathrm{Ni}_{10} \mathrm{Co}-\mathrm{BTC}, \mathrm{Ni}_{10} \mathrm{Co}-\mathrm{BTC} / \mathrm{KB}$ and $\mathrm{KB}$. The LSV curves in Figure $5 \mathrm{~b}$ display that the current density of $\mathrm{Ni}_{10} \mathrm{Co}-\mathrm{BTC} / \mathrm{KB}$ was higher than that of the pristine MOF or $\mathrm{KB}$ before the stability test, which could be due to a conductivity enhancement effect by the introduction of KB. After the stability test the achieved current density of the pristine MOF is higher than the composite and both are higher than the current density of $\mathrm{KB}$. The current densities of $\mathrm{Ni}_{10} \mathrm{Fe}-\mathrm{BTC}$ and of $\mathrm{KB}$ have declined after the stability test. $\mathrm{Ni}_{10} \mathrm{Co}-\mathrm{BTC}$, $\mathrm{Ni}_{10} \mathrm{Co}-\mathrm{BTC} / \mathrm{KB}$ and the commercial $\mathrm{Ni} / \mathrm{NiO}$ nanoparticles reach a higher current density after the stability test. The peaks from 1.3 to $1.4 \mathrm{~V}$ vs. RHE in Figure $5 \mathrm{~b}$ originated from the redox reaction of $\mathrm{Ni}^{2+/ 3+}[35,62,63]$. The redox peaks are less visible for $\mathrm{Ni}_{10} \mathrm{Fe}-\mathrm{BTC}$, which is due to the well-known suppressor effect of $\mathrm{Fe}$ for the $\mathrm{Ni}^{2+/ 3+}$ oxidation [64-66]. The changed current densities before and after the $1000 \mathrm{CVs}$ already depict that an activation is taking place in case of the $\mathrm{NiCo}$ samples and the $\mathrm{Ni} / \mathrm{NiO}$ nanoparticles. The efficiency of an electrocatalyst is normally checked with the overpotential at a current density (j) of $10 \mathrm{~mA} / \mathrm{cm}^{2}$, which relates to the approximate current density expected for a $10 \%$ efficient solar-to-fuel conversion device under sun illumination $[13,67,68]$. To have a more defined indicator the initial overpotential and the overpotential after the stability test to reach $10 \mathrm{~mA} / \mathrm{cm}^{2}$ should be considered. $\mathrm{Ni}_{10} \mathrm{Fe}-\mathrm{BTC}$ reaches $10 \mathrm{~mA} / \mathrm{cm}^{2}$ with an initial overpotential of $346 \mathrm{mV}$ and an overpotential of $344 \mathrm{mV}$ after the stability test. The measurement done after the stability test shows nearly identical values, which indicates that the material is stable in its OER performance. The results show that $\mathrm{Ni}_{10} \mathrm{Fe}-\mathrm{BTC}$ has a relatively good OER performance. The overpotentials needed to reach $10 \mathrm{~mA} / \mathrm{cm}^{2}$ before and after the stability test and Tafel slopes for $\mathrm{KB}, \mathrm{Ni}_{10} \mathrm{Co}-\mathrm{BTC} / \mathrm{KB}, \mathrm{Ni}_{10} \mathrm{Co}-\mathrm{BTC}$ and $\mathrm{Ni} / \mathrm{NiO}$ nanoparticles including the results of $\mathrm{Ni}_{10} \mathrm{Fe}-\mathrm{BTC}$ are listed in Table S4, SI. $\mathrm{Ni}_{10}$ Co-BTC $(\eta=378 \mathrm{mV} \rightarrow 337 \mathrm{mV}), \mathrm{Ni}_{10} \mathrm{Co}-\mathrm{BTC} / \mathrm{KB}(\eta=366 \mathrm{mV} \rightarrow 347 \mathrm{mV}) \mathrm{MOF}$ samples and the $\mathrm{Ni} / \mathrm{NiO}$ nanoparticles $(\eta=370 \mathrm{mV} \rightarrow 358 \mathrm{mV})$ all give a decreasing overpotential, which indicates an activation of the materials and an increased OER activity. The improvement of the activity of the materials reveal that the prior activation (10 CVs) was not sufficient and it also can correlate with the formation of, for example, a highly OER active $\mathrm{NiOOH}$ layer [69]. Only KB demonstrated a higher overpotential afterwards $(\eta=376 \mathrm{mV} \rightarrow 422 \mathrm{mV})$. KB exhibits worse OER activity after 1000 cycles due to carbon corrosion at high potentials in alkaline conditions $[70,71]$. The carbon corrosion can also be the limiting factor of the composite, since after the $1000 \mathrm{CVs}$ the $\mathrm{Ni}_{10} \mathrm{Co}-\mathrm{BTC}$-derived material provides the lowest overpotential with $337 \mathrm{mV}$. The $\mathrm{Ni}_{10} \mathrm{Co}-\mathrm{BTC} / \mathrm{KB}$ composite shows the best initial OER activity, but $\mathrm{Ni}_{10} \mathrm{Co}-\mathrm{BTC}$ has a stronger activation after the stability test and consequently a higher activity. 


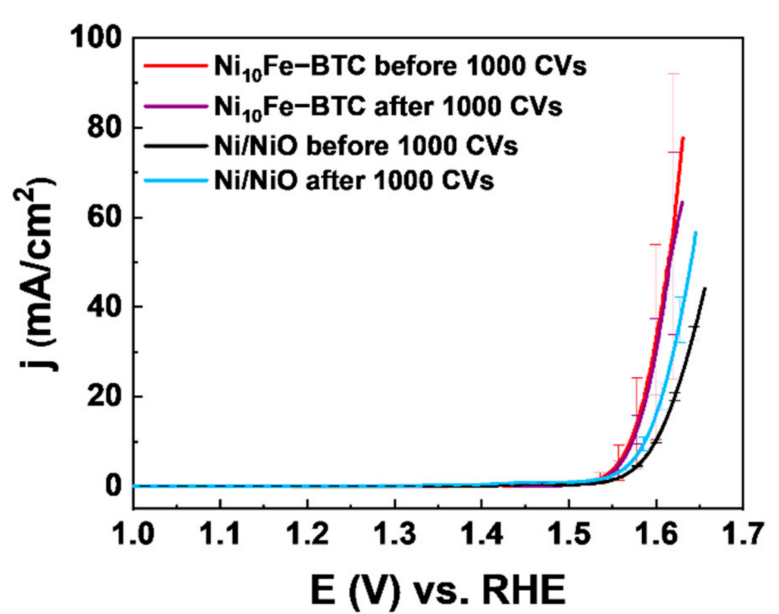

(a)

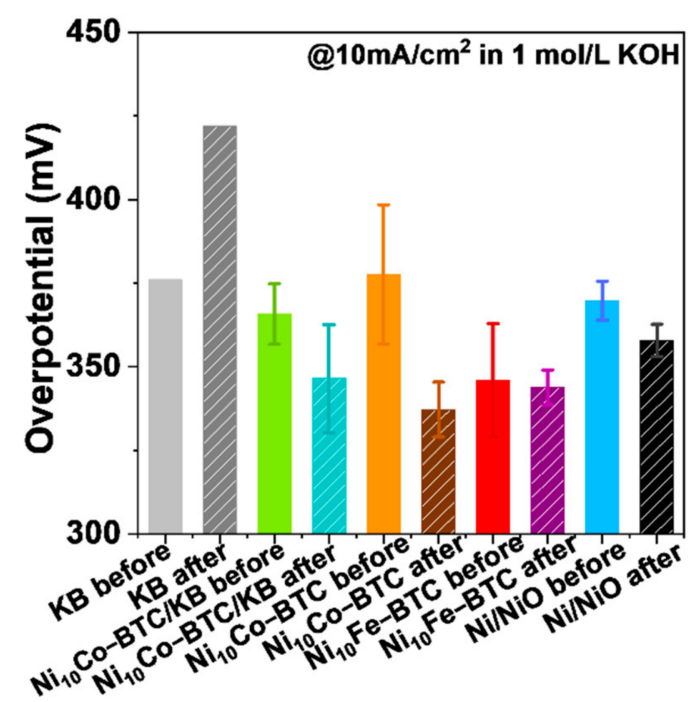

(c)

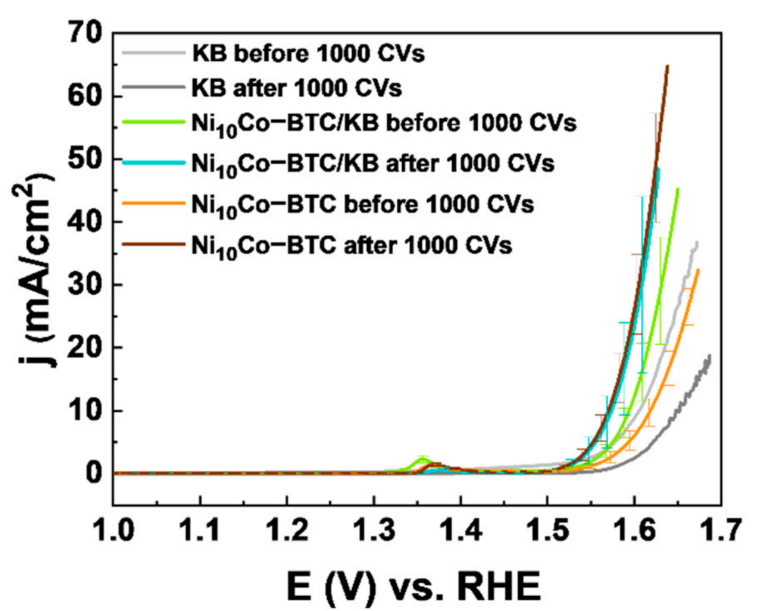

(b)

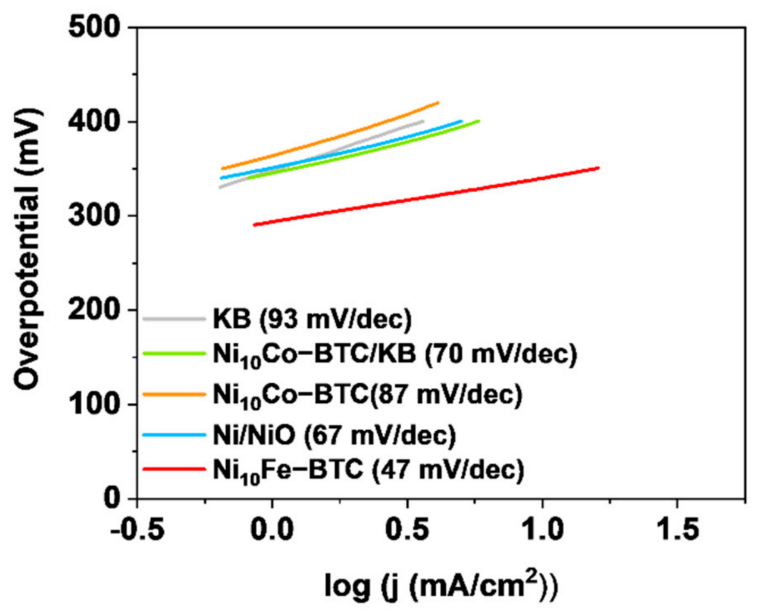

(d)

Figure 5. (a,b) LSV curves of $\mathrm{Ni}_{10} \mathrm{Fe}-\mathrm{BTC}$, Ni/NiO nanoparticles, $\mathrm{KB}, \mathrm{Ni}{ }_{10} \mathrm{Co}-\mathrm{BTC} / \mathrm{KB}$ and $\mathrm{Ni}_{10} \mathrm{Co}-$ BTC before and after $1000 \mathrm{CVs}$, (c) overpotentials calculated from (a,b), (d) Tafel plots.

The Tafel slopes (Figure $5 \mathrm{~d}$ ) of $\mathrm{Ni}_{10} \mathrm{Fe}-\mathrm{BTC}(47 \mathrm{mV} / \mathrm{dec}), \mathrm{Ni}_{10} \mathrm{Co}-\mathrm{BTC} / \mathrm{KB}(70 \mathrm{mV} / \mathrm{dec}$ ), $\mathrm{Ni}_{10} \mathrm{Co}-\mathrm{BTC}(87 \mathrm{mV} / \mathrm{dec})$ and $\mathrm{Ni} / \mathrm{NiO}$ nanoparticles $(67 \mathrm{mV} / \mathrm{dec})$ are in agreement with the reported values of Ni-BTC (71 mV/dec), $\mathrm{FeNi}_{10}-\mathrm{BTC}(60 \mathrm{mV} / \mathrm{dec}), \mathrm{Fe}_{3} \mathrm{Ni}-\mathrm{BTC}(49 \mathrm{mV} / \mathrm{dec})$, FeNi-BTC $(50 \mathrm{mV} / \mathrm{dec}) \mathrm{NiCo}_{2} \mathrm{O}_{4}$ (Precursor: NiCo-BTC) $(59.3 \mathrm{mV} / \mathrm{dec})$ and $\mathrm{Ni}(\mathrm{OH})_{2}$ $(65 \mathrm{mV} / \mathrm{dec})[17,35,40]$. The value of the Tafel slope can give insight into the rate determining step (rds) of the OER mechanism. Krasil'shchikov's OER mechanism is one of the more widely known mechanisms, which is described by Equations (4)-(7) with the corresponding Tafel slopes b [72,73].

$$
\begin{gathered}
\mathrm{M}+\mathrm{OH}^{-} \rightleftarrows \mathrm{MOH}+\mathrm{e}^{-} \quad \mathrm{b}=120 \mathrm{mV} / \mathrm{dec} \\
\mathrm{MOH}+\mathrm{OH}^{-} \rightleftarrows \mathrm{MO}^{-}+\mathrm{e}^{-} \quad \mathrm{b}=60 \mathrm{mV} / \mathrm{dec} \\
\mathrm{MO}^{-} \rightarrow \mathrm{MO}+\mathrm{e}^{-} \quad \mathrm{b}=45 \mathrm{mV} / \mathrm{dec} \\
2 \mathrm{MO} \rightarrow 2 \mathrm{M}+\mathrm{O}_{2} \quad \mathrm{~b}=19 \mathrm{mV} / \mathrm{dec}
\end{gathered}
$$


For $\mathrm{Ni}_{10} \mathrm{Fe}-\mathrm{BTC}(47 \mathrm{mV} / \mathrm{dec}$ ) Equation (6) appears to be the rds of the OER mechanism. The most likely rds of the OER mechanism of $\mathrm{Ni}_{10} \mathrm{Co}-\mathrm{BTC} / \mathrm{KB}(70 \mathrm{mV} / \mathrm{dec})$ and $\mathrm{Ni} / \mathrm{NiO}$ nanoparticles $(67 \mathrm{mV} / \mathrm{dec})$ seem to be Equation (5). The Tafel slope of $\mathrm{Ni}_{10} \mathrm{Co}-\mathrm{BTC}$ $(87 \mathrm{mV} / \mathrm{dec})$ is in between the values of Equations (4) and (5), which makes it difficult to clearly assign it to one of the two reaction steps.

MOFs often act as sacrificial agents to generate structured carbon-based metal oxide materials as efficient electrocatalysts $[27,32,35]$. To test the stability of the synthesized MOF materials in the alkaline electrolyte $\mathrm{Ni}_{10} \mathrm{Co}-\mathrm{BTC}, \mathrm{Ni}_{10} \mathrm{Co}-\mathrm{BTC} / \mathrm{KB}$ and $\mathrm{Ni}_{10} \mathrm{Fe}-\mathrm{BTC}$ were soaked in $1 \mathrm{~mol} / \mathrm{L} \mathrm{KOH}$ for $24 \mathrm{~h}$.

The PXRD patterns of all three samples (Figure 6) display transitions of the MOF structures to their (oxy)hydroxides. $\mathrm{Ni}_{10} \mathrm{Co}-\mathrm{BTC}$ and $\mathrm{Ni}_{10} \mathrm{Co}-\mathrm{BTC} / \mathrm{KB}$ (Figure 6a) exhibit structural changes to $\alpha-\mathrm{Ni}(\mathrm{OH})_{2}$ (ICDD:38-0715), $\beta-\mathrm{Ni}(\mathrm{OH})_{2}$ (ICDD:14-0117), $\beta-\mathrm{NiOOH}$ (ICDD:06-0141) and/or $\gamma$-NiOOH (ICDD:06-0075) [74]. The relationship between these nickelhydroxides and oxidehydroxides is explained in the Supplementary Information. It is presently not possible, however, to quantify the components in a mixed $\alpha / \beta-\mathrm{Ni}(\mathrm{OH})_{2}$ sample from XPS results [75]. According to literature [75] $\alpha$ - and $\beta-\mathrm{Ni}(\mathrm{OH})_{2}$ could be possibly distinguished from each other by FT-IR spectroscopy. FT-IR spectra for the samples after letting them soak in $1 \mathrm{~mol} / \mathrm{L} \mathrm{KOH}$ for $24 \mathrm{~h}$ only indicated also the formation of $\alpha$ - and $\beta-\mathrm{Ni}(\mathrm{OH})_{2}$, albeit without being able to differentiate between them (Figure S7 and Table S5 in the SI). The diffraction patterns for $\alpha-\mathrm{Co}(\mathrm{OH})_{2}$ and $\gamma-\mathrm{CoOOH}$ match the given $\mathrm{Ni}(\mathrm{OH})_{2}$ and $\mathrm{NiOOH}$ diffraction patterns [76]. Similar to $\mathrm{Ni}_{10} \mathrm{Co}-\mathrm{BTC}$ and $\mathrm{Ni}_{10} \mathrm{Co}-\mathrm{BTC} / \mathrm{KB}$ the PXRD pattern of $\mathrm{Ni}_{10} \mathrm{Fe}-\mathrm{BTC}$ after $24 \mathrm{~h}$ in $1 \mathrm{~mol} / \mathrm{L} \mathrm{KOH}$ (Figure $6 \mathrm{~b}$ ) shows a clear loss of crystallinity of the material and indicates formation of $\alpha-\mathrm{Ni}(\mathrm{OH})_{2}$ (ICDD:38-0715) and/or $\alpha$-FeOOH (ICDD: 29-0713) [74,77]. The change in the structure of $\mathrm{Ni}_{10} \mathrm{Co} / \mathrm{Fe}-\mathrm{BTC}$ to $\mathrm{Ni}(\mathrm{OH})_{2}, \mathrm{Co}(\mathrm{OH})_{2}$ and/or to $\mathrm{NiOOH}, \mathrm{CoOOH}$ and /or $\mathrm{FeOOH}$ is in agreement to reported observations [78]. The transition to their (oxy)hydroxides fits to the activation which could have been seen through the decrease of their overpotentials (Table S4, SI). Furthermore, transmission electron microscopy (TEM) images were made of the synthesized MOF samples before and after the electrochemical stability tests (1000 CVs). The TEM images (Figures S4-S6, SI) also indicate that a transition of the original MOF morphology takes place. The $\mathrm{Ni}_{10} \mathrm{Co}-\mathrm{BTC} / \mathrm{KB}$ TEM images (Figure S6, SI) illustrate that the larger MOF particle transformed into nanoparticles. The homogenous $\mathrm{Ni}_{10} \mathrm{Co}-\mathrm{BTC}$ MOF particle (Figure S5, SI) changed into a carbon-based material, which contains metal (oxy)hydroxides nanoparticles. The lattice spacings of both NiCo samples (Figures S5d and S6c) could be obtained. The values of the lattice spacings fit to values of reported $\mathrm{Ni}(\mathrm{OH})_{2}[79]$ and $\mathrm{Co}(\mathrm{OH})_{2}$, which was formed during electrochemical tests of the MOF ZIF67 [80]. For $\mathrm{Ni}_{10} \mathrm{Fe}-\mathrm{BTC}$ (Figure S4, SI) a loss of the former cubic shape of the particle can be observed and out of the resulting new morphology no lattice spacings could be gained. The changed morphology of all samples corroborates the structural changes, which could be seen through the stability test of the synthesized materials in the alkaline electrolyte. 


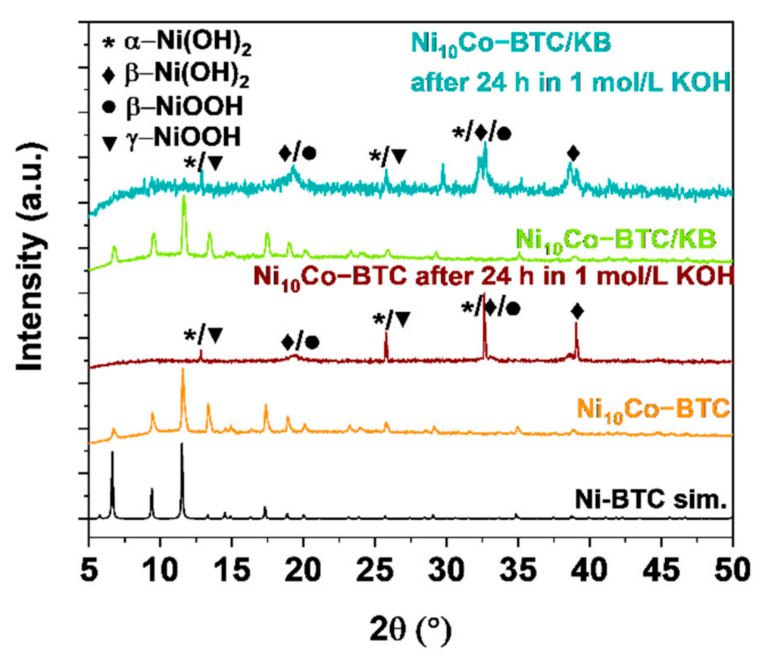

(a)

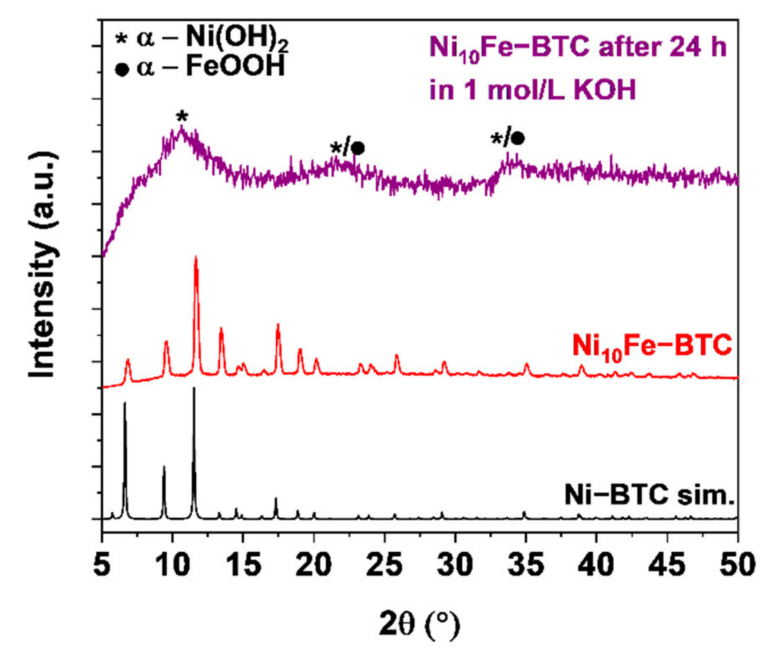

(b)

Figure 6. PXRD patterns of (a) experimental $\mathrm{Ni}_{10} \mathrm{Co}-\mathrm{BTC}$ (orange), $\mathrm{Ni}_{10} \mathrm{Co}-\mathrm{BTC} / \mathrm{KB}$ (green), $\mathrm{Ni}_{10} \mathrm{Co}-$ BTC, $\mathrm{Ni}_{10} \mathrm{Co}-\mathrm{BTC} / \mathrm{KB}$ after $24 \mathrm{~h}$ in $1 \mathrm{~mol} / \mathrm{L} \mathrm{KOH}$ (brown and dark green) and simulated Ni-BTC (black) (CCDC Nr. 802889), (b) experimental Ni ${ }_{10} \mathrm{Fe}-\mathrm{BTC}$ (red), $\mathrm{Ni}_{10} \mathrm{Fe}-\mathrm{BTC}$ after $24 \mathrm{~h}$ in $1 \mathrm{~mol} / \mathrm{L}$ $\mathrm{KOH}$ (purple) and simulated Ni-BTC (black) (CCDC Nr. 802889); $\alpha-\mathrm{Ni}(\mathrm{OH})_{2}$ marked by an asterisk ${ }^{*}$ (ICDD: 38-0715), $\beta-\mathrm{Ni}(\mathrm{OH})_{2}$ marked by a diamond ( $)$ (ICDD:14-0117), $\beta-\mathrm{NiOOH}$ marked by a circle $(\bullet)$ (ICDD:06-0141) and $\gamma-\mathrm{NiOOH}$ marked by a triangle ( $\boldsymbol{\nabla})$ (ICDD:06-0075) and $\alpha-\mathrm{FeOOH}$ marked by a circle $(\bullet)$ (ICDD: 29-0713).

\section{Materials and Methods}

\subsection{Materials}

The used chemicals were obtained from commercial sources and no further purification was carried out. Ketjenblack EC 600 JD was purchased from AkzoNobel, Amsterdam. The Netherlands.

\subsection{Synthesis of the Ni-BTC Analogs}

Synthesis of $\mathrm{Ni}_{10} \mathrm{Fe}-\mathrm{BTC}$ : $\mathrm{Ni}_{10} \mathrm{Fe}-\mathrm{BTC}$ was synthesized according to the literature [40]. $48 \mathrm{mg}(0.11 \mathrm{mmol}) \mathrm{Fe}\left(\mathrm{NO}_{3}\right)_{3} * 9 \mathrm{H}_{2} \mathrm{O}, 349 \mathrm{mg}(1.2 \mathrm{mmol}) \mathrm{Ni}\left(\mathrm{NO}_{3}\right)_{2} * 6 \mathrm{H}_{2} \mathrm{O}, 205 \mathrm{mg}$ (0.98 $\mathrm{mmol}) \mathrm{H}_{3} \mathrm{BTC}$ and $55 \mathrm{mg}(0.67 \mathrm{mmol})$ 2-MeImH were dissolved in $15 \mathrm{~mL} \mathrm{DMF}$ at room temperature (RT) and stirred for $30 \mathrm{~min}$. The prepared solution was transferred into a Teflon-lined stainless-steel autoclave and then heated to $170{ }^{\circ} \mathrm{C}$ for $48 \mathrm{~h}$. The resulting dark olive-green precipitate was centrifuged ( $25 \mathrm{~min}, 5000 \mathrm{rpm}$ ). The precipitate was washed one time with DMF and two times with EtOH and centrifuged again (15 min, $6000 \mathrm{rpm})$. The product was dried overnight in a vacuum drying cabinet at $90{ }^{\circ} \mathrm{C}$ and $<50$ mbar.

Yield ( $\left.\mathrm{Ni}_{10} \mathrm{Fe}-\mathrm{BTC}\right): 276 \mathrm{mg}$

Synthesis of $\mathrm{Ni}_{10} \mathrm{Co}-\mathrm{BTC}$ and $\mathrm{Ni}_{10} \mathrm{Co}-\mathrm{BTC} / \mathrm{KB}$ : $\mathrm{Ni}{ }_{10} \mathrm{Co}-\mathrm{BTC}$ and $\mathrm{Ni}{ }_{10} \mathrm{Co}-\mathrm{BTC} / \mathrm{KB}$ were synthesized according to the literature with some modifications [40]. Varying from this synthesis procedure $\mathrm{Co}\left(\mathrm{NO}_{3}\right)_{2} * 6 \mathrm{H}_{2} \mathrm{O}$ was used instead of $\mathrm{Fe}\left(\mathrm{NO}_{3}\right)_{3} * 9 \mathrm{H}_{2} \mathrm{O}$ for the synthesis of $\mathrm{Ni}_{10} \mathrm{Co}-\mathrm{BTC}$ and $\mathrm{Ni}_{10} \mathrm{Co}-\mathrm{BTC} / \mathrm{KB}$.

For the $\mathrm{Ni}_{10} \mathrm{Co}-\mathrm{BTC}$ sample $35 \mathrm{mg}(0.12 \mathrm{mmol}) \mathrm{Co}\left(\mathrm{NO}_{3}\right)_{2} * 6 \mathrm{H}_{2} \mathrm{O}, 349 \mathrm{mg}(1.2 \mathrm{mmol})$, $\mathrm{Ni}\left(\mathrm{NO}_{3}\right)_{2} * 6 \mathrm{H}_{2} \mathrm{O}, 205 \mathrm{mg}(0.98 \mathrm{mmol}) \mathrm{H}_{3} \mathrm{BTC}$ and $55 \mathrm{mg}(0.67 \mathrm{mmol})$ 2-MeImH were dissolved in $20 \mathrm{~mL}$ DMF at RT and stirred for $30 \mathrm{~min}$. For the $\mathrm{Ni}_{10} \mathrm{Co}-\mathrm{BTC} / \mathrm{KB}$ sample the same amounts were used and $70 \mathrm{mg} \mathrm{KB}$ additionally added. The prepared solution was transferred into a Teflon-lined stainless-steel autoclave and then heated to $170{ }^{\circ} \mathrm{C}$ for $48 \mathrm{~h}$. The resulting dark olive-green $\left(\mathrm{Ni}_{10} \mathrm{Co}-\mathrm{BTC}\right)$ and black $\left(\mathrm{Ni}_{10} \mathrm{Co}-\mathrm{BTC} / \mathrm{KB}\right)$ precipitates were centrifuged ( $25 \mathrm{~min}, 5000 \mathrm{rpm}$ ). The precipitates were washed for one time with DMF and 
for two times with $\mathrm{EtOH}$ and centrifuged again $(15 \mathrm{~min}, 6000 \mathrm{rpm})$. The products were dried overnight in a vacuum drying cabinet at $90{ }^{\circ} \mathrm{C}$ and $<50$ mbar.

Yield $\left(\mathrm{Ni}_{10} \mathrm{Co}-\mathrm{BTC}\right): 328 \mathrm{mg}$

Yield $\left(\mathrm{Ni}_{10} \mathrm{Co}-\mathrm{BTC} / \mathrm{KB}\right): 357 \mathrm{mg}$

\subsection{Materials Characterization}

Powder X-ray diffraction (PXRD) measurements were performed at ambient temperature on a Bruker D2 Phaser powder diffractometer with a power of $300 \mathrm{~W}$ and an acceleration voltage of $30 \mathrm{kV}$ at $10 \mathrm{~mA}$ using $\mathrm{Cu}-\mathrm{K} \alpha$ radiation $(\lambda=1.5418 \AA)$. The diffractograms were obtained on a low background flat silicon sample holder and evaluated with the Match 3.11 software. The samples were measured in the range from 5 to $50^{\circ} 2 \theta$ with a scan speed of $2 \mathrm{~s} /$ step and $0.057^{\circ}(2 \theta)$ step size.

Fourier transform infrared spectroscopy (FT-IR) spectra were recorded in $\mathrm{KBr}$ mode on a Bruker TENSOR 37 IR spectrometer in the range of $4000-400 \mathrm{~cm}^{-1}$.

Nitrogen sorption measurements were performed with a Nova 4000e from Quantachrome at $77 \mathrm{~K}$. The sorption isotherms were evaluated with the NovaWin 11.03 software. Prior to the measurement the materials were first degassed under vacuum $\left(<10^{-2} \mathrm{mbar}\right)$ at $120{ }^{\circ} \mathrm{C}$ for $5 \mathrm{~h}$. Brunauer-Emmett-Teller (BET) surface areas were determined from the $\mathrm{N}_{2}$-sorption adsorption isotherms and the pore size distributions were derived by non-local density functional theory (NLDFT) calculations based on $\mathrm{N}_{2}$ at $77 \mathrm{~K}$ on carbon with slit/cylindrical pores.

Thermogravimetric analyses (TGA) were carried out with a Netzsch TG 209 F3 Tarsus device equipped with an $\mathrm{Al}$ crucible with a heating rate of $5 \mathrm{~K} / \mathrm{min}$ under nitrogen atmosphere.

CHN elemental analyses were conducted with a Vario Mirco Cube from Elementar Analysentechnik.

Flame atomic absorption spectroscopy (AAS) was conducted with a PinAAcle 900T from PerkinElmer. Weighted samples were heated to dryness with $15 \mathrm{~mL}$ of aqua regia for two times and afterwards stirred with $10 \mathrm{~mL}$ of aqua regia overnight. The solution was carefully filtered and diluted with Millipore water to a volume of $25 \mathrm{~mL}$. The resulting solutions were further diluted with Millipore water (1:50) for the AAS measurements.

Scanning electron microscopy (SEM) images were collected with a JEOL JSM-6510 LV QSEM advanced electron microscope with a $\mathrm{LaB}_{6}$ cathode at $20 \mathrm{kV}$. The microscope was equipped with a Bruker Xflash 410 silicon drift detector and the Bruker ESPRIT software for energy-dispersive $\mathrm{X}$-ray (EDX) analysis which was used to record EDX spectra and EDX mapping. The small amount of $\mathrm{Cu}, \mathrm{Zn}$ and $\mathrm{Au}$ found in the EDX spectra are due to the brass sample holder and the sputtering of the sample with gold prior to the investigation.

Transmission electron microscopy (TEM) images of the MOF samples before the electrochemical tests were recorded on a FEI Tecnai G2 F20 electron microscope operated at $200 \mathrm{kV}$ accelerating voltage equipped with a Gatan UltraScan 1000P detector. TEM samples were prepared by drop-casting the diluted material on $200 \mu \mathrm{m}$ carbon-coated copper grids. TEM images of the samples after the electrochemical tests were obtained using a FEI Titan, 80-300 TEM with a $\mathrm{C}_{\mathrm{s}}$ corrector for the objective lens $(\mathrm{CEOS} \mathrm{GmbH})$ operated at $300 \mathrm{kV}$. After the electrochemical test the electrode was rinsed in isopropanol and sonicated until all the layers from the surface of the electrode were dissolved into the solution. Again, the TEM samples were prepared by drop-casting the solution onto the TEM grid. Particle sizes and size distribution were determined manually using the Gatan Digital Micrograph software. For the size distribution over 150 individual particles were analyzed.

\subsection{Electrocatalytic Measurements}

The electrocatalytic OER measurements were conducted with a SP-150 Potentiostat form BioLogic Science Instruments and with a three-electrode setup. As reference electrode a mercury/mercury oxide $(\mathrm{Hg} / \mathrm{HgO})$ electrode was used. As counter electrode a $\mathrm{Pt}$ wire was used. As working electrode, a rotating disc electrode (RDE), here a glassy 
carbon electrode (GCE), was used. For the electrocatalyst inks $8 \mathrm{mg}$ of electrocatalyst was dispersed in $1.5 \mathrm{~mL}$ isopropanol, $0.5 \mathrm{~mL}$ deionized water, and $20 \mu \mathrm{L}$ Nafion (5 wt.\%) and sonicated for $40 \mathrm{~min}$. Catalyst loading was $0.2 \mathrm{mg} / \mathrm{cm}^{2}$ by drop casting $10 \mu \mathrm{L}$ ink on the GC surface (geometric area of $0.196 \mathrm{~cm}^{2}$ ). All the powders dispersed well, forming a stable and homogeneous ink. After drying, the film fully covered the GC electrode. All the electrochemical measurements were conducted in $1 \mathrm{~mol} / \mathrm{L}$ concentrated Ar-saturated $\mathrm{KOH}$ electrolyte, which has been purged with $\mathrm{O}_{2}$ for 20 min prior to the OER experiments, with a rotation speed of $1600 \mathrm{rpm}$ at RT. An activation protocol was used before the LSV measurements by cycling the working electrode between $1.0 \mathrm{~V}$ and $1.7 \mathrm{~V}$ vs. RHE at a scan rate of $100 \mathrm{mV} / \mathrm{s}$ for 10 cycles. The LSV polarization curves were recorded in a potential range of 1.0 to $1.7 \mathrm{~V}$ vs. RHE at a sweep rate of $5 \mathrm{mV} / \mathrm{s}$ without iR correction. The potential applied to the ohmic resistance was extracted later manually. The cycling stability was measured by comparing LSV curves before and after 1000 cycles between 1.0-1.7 V with a scan rate of $100 \mathrm{mV} / \mathrm{s}$.

The measured potentials (vs. $\mathrm{Hg} / \mathrm{HgO}$ ) were converted in potentials vs. RHE with the following Equation (8) [81]:

$$
\mathrm{E}_{\mathrm{RHE}}=\mathrm{E}_{(\mathrm{Hg} / \mathrm{HgO})}+0.059 \mathrm{pH}+\mathrm{E}_{(\mathrm{Hg} / \mathrm{HgO})}^{\circ}
$$

with $\mathrm{E}_{\mathrm{RHE}}=$ converted potential vs. $\mathrm{RHE}, \mathrm{E}_{(\mathrm{Hg} / \mathrm{HgO})}=$ measured potential and $\mathrm{E}^{\circ}(\mathrm{Hg} / \mathrm{HgO})$ = standard potential of the $\mathrm{Hg} / \mathrm{HgO}$ reference electrode.

The overpotential was calculated as shown in Equation (1): $\eta_{\mathrm{OER}}=\mathrm{E}_{\mathrm{RHE}}-\mathrm{E}^{\circ}(1.23 \mathrm{~V})$. To reduce the experimental contingency error, at least three repeated measurements were carried out for a sample and the average curves with their error bars were compared in the figures. The OER performance of MOF samples were compared with commercial $\mathrm{Ni} / \mathrm{NiO}$ nanoparticles (Alfa Aesar, Heysham, UK; VWR, International GmbH, Darmstadt, Germany) and KB (AkzoNobel, Amsterdam, The Netherlands).

\section{Conclusions}

Different mixed-metal Ni-BTC analogs with cobalt and iron doping were synthesized, characterized, tested for their performance in the OER and compared to the reference of $\mathrm{Ni} / \mathrm{NiO}$ nanoparticles and $\mathrm{KB}$. The pristine MOFs $\mathrm{Ni}_{10} \mathrm{Co}-\mathrm{BTC}$ and $\mathrm{Ni}_{10} \mathrm{Fe}-\mathrm{BTC}$, as well as the composite $\mathrm{Ni}_{10} \mathrm{Co}-\mathrm{BTC} / \mathrm{KB}$ could be prepared easily through a one-step solvothermal reaction. To compensate the shortcoming of low MOF conductivity for electrocatalysis, the highly porous and conductive carbon material KB was added, which can also support the transport of electrolyte ions and evolved gases. The MOF electrocatalysts are not stable under the implemented alkaline conditions for the electrocatalytic measurements, which again emphasizes that MOFs can be regarded as sacrificial agents. Nevertheless, the resulting, stabilized materials all evince good performances in the OER. Comparing the overpotentials of $\mathrm{Ni}_{10} \mathrm{Co}-\mathrm{BTC}(\eta=378 \mathrm{mV})$ and $\mathrm{Ni}_{10} \mathrm{Co}-\mathrm{BTC} / \mathrm{KB}(\eta=366 \mathrm{mV})$ before the stability test, the composite shows a better performance for the OER, but afterward, the $\mathrm{Ni}_{10} \mathrm{Co}$-BTC-derived electrocatalyst exhibits a lower overpotential $(337 \mathrm{mV})$ than the $\mathrm{Ni}_{10} \mathrm{Co}-\mathrm{BTC} / \mathrm{KB}$-derived electrocatalyst $(347 \mathrm{mV})$. This illustrates that the conductivity, which could have been increased by introducing $\mathrm{KB}$, is not the key factor limiting the OER activity of the $\mathrm{Ni}_{10} \mathrm{Co}-\mathrm{BTC}$-derived electrocatalyst. However, a clearly positive effect of $\mathrm{KB}$ in the $\mathrm{Ni}_{10} \mathrm{Co}-\mathrm{BTC} / \mathrm{KB}$-derived material is a decreased Tafel slope with $70 \mathrm{mV} \mathrm{dec}{ }^{-1}$ in comparison to the $\mathrm{Ni}_{10} \mathrm{Co}$-BTC-derived material with $87 \mathrm{mV} \mathrm{dec}^{-1}$, which indicates a more favorable kinetics of the OER for the composite-derived material. The $\mathrm{Ni}_{10}$ Fe-BTC-dervied electrocatalyst remains the most stable material in the electrochemical OER performance $(\eta=346 \mathrm{mV} \rightarrow 344 \mathrm{mV})$ and has the lowest Tafel slope of $47 \mathrm{mV} \mathrm{dec}{ }^{-1}$, showing that the activity of Ni-electrocatalysts can be improved to some extent with incorporated iron. The results of the Tafel analysis show that the introduction of $\mathrm{KB}$ in the $\mathrm{Ni}_{10} \mathrm{Co}-\mathrm{BTC} \mathrm{MOF}$ facilitates to overcome the kinetic barrier of the complex four electron-proton coupled OER transfer process. The composite material $\mathrm{Ni}_{10} \mathrm{Co}-\mathrm{BTC} / \mathrm{KB}$ and the presented protocol give insight into the possibility of combining MOFs, as sacrificial agents, with $\mathrm{KB}$ to generate 
new MOF-based electrocatalysts for electrocatalytic reactions. Further research should now be conducted to investigate potential other nickel-metal combinations to optimize the electrocatalytic performance.

Supplementary Materials: The following supporting information can be downloaded online. Table S1. Elemental analysis of the MOF samples. Table S2. Assignments of IR-bands of Ni-BTC analogs $\left(\mathrm{cm}^{-1}\right)$. Table S3. BET-surface areas and total pore volumes of the Ni-BTC analogs. Table S4. Overpotentials (at $10 \mathrm{~mA} / \mathrm{cm}^{2}$ ) and Tafel slopes for $\mathrm{Ni}_{10} \mathrm{Fe}-\mathrm{BTC}, \mathrm{Ni}_{10} \mathrm{Co}-\mathrm{BTC}, \mathrm{Ni}_{10} \mathrm{Co}-\mathrm{BTC} / \mathrm{KB}, \mathrm{KB}$ and $\mathrm{Ni} / \mathrm{NiO}$ nanoparticles done with a GCE (loading: $0.2 \mathrm{mg} / \mathrm{cm}^{2}$ ) with a scan rate of $5 \mathrm{mV} / \mathrm{s}$ in a $1.0 \mathrm{~mol} / \mathrm{L} \mathrm{KOH}$ electrolyte. Figure S1. TGA curves of (a) $\mathrm{Ni}_{10} \mathrm{Fe}-\mathrm{BTC}$, (b) $\mathrm{Ni}_{10} \mathrm{Co}-\mathrm{BTC}$, (c) $\mathrm{Ni}_{10} \mathrm{Co}-$ $\mathrm{BTC} / \mathrm{KB}$ and (d) $\mathrm{KB}$ under $\mathrm{N}_{2}$ atmosphere with a heating rate of $5 \mathrm{~K} / \mathrm{min}$. Figure S2. SEM-EDX spectra of (a) $\mathrm{Ni}_{10} \mathrm{Fe}-\mathrm{BTC}$, (b) $\mathrm{Ni}_{10} \mathrm{Co}-\mathrm{BTC}$ and (c) $\mathrm{Ni}_{10} \mathrm{Co}-\mathrm{BTC} / \mathrm{KB}$. Figure S3. (a,b) SEM images and (c) SEM-EDX spectra of KB. Figure S4. TEM images of $\mathrm{Ni}_{10} \mathrm{Fe}-\mathrm{BTC}$ (a) before (shown particle size: $3.1 \mu \mathrm{m})$ and $(\mathrm{b}-\mathrm{d})$ after $1000 \mathrm{CVs}$. Figure S5. TEM images of $\mathrm{Ni}_{10} \mathrm{Co}-\mathrm{BTC}(\mathrm{a})$ before and $(\mathrm{b}-\mathrm{d})$ after $1000 \mathrm{CVs}$ (shown particle size in (b): $2.8 \mu \mathrm{m}$; displayed particles in (c) give the average diameter of $20 \mathrm{~nm} \pm 9 \mathrm{~nm}$; (d) the lattice spacings and grain boundaries are illustrated in red and red lines, respectively). Figure S6. TEM images of $\mathrm{Ni}_{10} \mathrm{Co}-\mathrm{BTC} / \mathrm{KB}$ (a) before (shown particle size: $4.4 \mu \mathrm{m}$ ) and $(b, c)$ after $1000 \mathrm{CVs}($ (c) the lattice spacings and grain boundaries are illustrated in red and red lines, respectively.) and (d) histogram of $\mathrm{Ni}_{10} \mathrm{Co}-\mathrm{BTC} / \mathrm{KB}$ after $1000 \mathrm{CVs}$ determined from (b) give the average diameter of $5 \mathrm{~nm} \pm 1 \mathrm{~nm}(1 \sigma)$. Scheme S1. Schematic relation between $\beta-\mathrm{Ni}(\mathrm{OH})_{2}$, $\alpha-\mathrm{Ni}(\mathrm{OH})_{2}, \beta-\mathrm{NiOOH}$ and $\gamma-\mathrm{NiOOH}$. Figure S7. FT-IR spectra of (a) $\mathrm{Ni}_{10} \mathrm{Co}-\mathrm{BTC}$ after $24 \mathrm{~h}$ in $1 \mathrm{~mol} / \mathrm{L} \mathrm{KOH}$ (dark green) and (b) comparison with $\mathrm{Ni}_{10} \mathrm{Co}-\mathrm{BTC}$ (green), (c) $\mathrm{Ni}_{10} \mathrm{Co}-\mathrm{BTC} / \mathrm{KB}$ after $24 \mathrm{~h}$ in $1 \mathrm{~mol} / \mathrm{L} \mathrm{KOH}$ (brown) and (d) comparison with $\mathrm{Ni}_{10} \mathrm{Co}-\mathrm{BTC} / \mathrm{KB}$ (orange), (e) $\mathrm{Ni}_{10} \mathrm{Fe}-\mathrm{BTC}$ after $24 \mathrm{~h}$ in $1 \mathrm{~mol} / \mathrm{L} \mathrm{KOH}$ (purple) and (f) comparison with $\mathrm{Ni}_{10} \mathrm{Fe}-\mathrm{BTC}$ (red). Table S5. Assignments of IR-bands of Ni-BTC analogs after $24 \mathrm{~h}$ in $1 \mathrm{~mol} / \mathrm{L} \mathrm{KOH}\left(\mathrm{cm}^{-1}\right)$. References [82-84] are cited in the supplementary materials.

Author Contributions: Conceptualization, C.J. and L.S.; Methodology, L.S.; Validation, L.S. and M.S.; Formal analysis, L.S.; Investigation, L.S., W.J., M.S., A.S., D.W. and L.R.; Resources, C.J.; Data Curation, L.S.; Writing-Original Draft, L.S.; Writing—Review \& Editing, C.J., W.J. and M.S.; Visualization, L.S.; Supervision, C.J.; Project administration, C.J.; Funding acquisition, C.J. All authors have read and agreed to the published version of the manuscript.

Funding: The research of C.J. was supported by a joint National Natural Science Foundation of China-Deutsche Forschungsgemeinschaft (NSFC-DFG) project (DFG JA466/39-1).

Institutional Review Board Statement: Not applicable.

Informed Consent Statement: Not applicable.

Data Availability Statement: The data presented in this study are available on request from the corresponding author.

Conflicts of Interest: The authors declare that they have no known competing financial interest or personal relationships that could have appeared to influence the work reported in this paper.

\section{References}

1. IEA. CO2 Emissions from Fuel Combustion 2019_Highlights; IEA: Paris, France, 2019.

2. Özturk, S.; Xiao, Y.-X.; Dietrich, D.; Giesen, B.; Barthel, J.; Ying, J.; Yang, X.-Y.; Janiak, C. Nickel nanoparticles supported on a covalent triazine framework as electrocatalyst for oxygen evolution reaction and oxygen reduction reactions. Beilstein $J$. Nanotechnol. 2020, 11, 770-781. [CrossRef]

3. Seh, Z.W.; Kibsgaard, J.; Dickens, C.F.; Chorkendorff, I.; Nørskov, J.K.; Jaramillo, T.F. Combining theory and experiment in electrocatalysis: Insights into materials design. Science 2017, 355, eaad4998. [CrossRef] [PubMed]

4. Roger, I.; Shipman, M.A.; Symes, M.D. Earth-abundant catalysts for electrochemical and photoelectrochemical water splitting. Nat. Rev. Chem. 2017, 1, 3. [CrossRef]

5. Zheng, S.; Li, X.; Yan, B.; Hu, Q.; Xu, Y.; Xiao, X.; Xue, H.; Pang, H. Transition-Metal (Fe, Co, Ni) Based Metal-Organic Frameworks for Electrochemical Energy Storage. Adv. Energy Mater. 2017, 7, 1602733. [CrossRef]

6. Zhuang, L.; Ge, L.; Yang, Y.; Li, M.; Jia, Y.; Yao, X.; Zhu, Z. Ultrathin Iron-Cobalt Oxide Nanosheets with Abundant Oxygen Vacancies for the Oxygen Evolution Reaction. Adv. Mater. 2017, 29, 1606793. [CrossRef] [PubMed] 
7. Han, L.; Dong, S.; Wang, E. Transition-Metal (Co, Ni, and Fe)-Based Electrocatalysts for the Water Oxidation Reaction. Adv. Mater. 2016, 28, 9266-9291. [CrossRef] [PubMed]

8. Jiao, Y.; Zheng, Y.; Jaroniec, M.; Qiao, S.Z. Design of electrocatalysts for oxygen- and hydrogen-involving energy conversion reactions. Chem. Soc. Rev. 2015, 44, 2060-2086. [CrossRef] [PubMed]

9. Tahir, M.; Pan, L.; Idrees, F.; Zhang, X.; Wang, L.; Zou, J.-J.; Wang, Z.L. Electrocatalytic oxygen evolution reaction for energy conversion and storage: A comprehensive review. Nano Energy 2017, 37, 136-157. [CrossRef]

10. Bandal, H.; Koteshwara Reddy, K.; Chaugule, A.; Kim, H. Iron-based heterogeneous catalysts for oxygen evolution reaction; change in perspective from activity promoter to active catalyst. J. Power Sources 2018, 395, 106-127. [CrossRef]

11. Wang, J.; Cui, W.; Liu, Q.; Xing, Z.; Asiri, A.M.; Sun, X. Recent Progress in Cobalt-Based Heterogeneous Catalysts for Electrochemical Water Splitting. Adv. Mater. 2016, 28, 215-230. [CrossRef]

12. Suen, N.-T.; Hung, S.-F.; Quan, Q.; Zhang, N.; Xu, Y.-J.; Chen, H.M. Electrocatalysis for the oxygen evolution reaction: Recent development and future perspectives. Chem. Soc. Rev. 2017, 46, 337-365. [CrossRef] [PubMed]

13. Wei, C.; Rao, R.R.; Peng, J.; Huang, B.; Stephens, I.E.L.; Risch, M.; Xu, Z.J.; Shao-Horn, Y. Recommended Practices and Benchmark Activity for Hydrogen and Oxygen Electrocatalysis in Water Splitting and Fuel Cells. Adv. Mater. 2019, 31, 1806296. [CrossRef] [PubMed]

14. Farid, S.; Ren, S.; Hao, C. MOF-derived metal/carbon materials as oxygen evolution reaction catalysts. Inorg. Chem. Commun. 2018, 94, 57-74. [CrossRef]

15. Anantharaj, S.; Ede, S.R.; Karthick, K.; Sankar, S.S.; Sangeetha, K.; Karthik, P.E.; Kundu, S. Precision and correctness in the evaluation of electrocatalytic water splitting: Revisiting activity parameters with a critical assessment. Energy Environ. Sci. 2018, 11,744-771. [CrossRef]

16. Li, Y.; Du, X.; Huang, J.; Wu, C.; Sun, Y.; Zou, G.; Yang, C.; Xiong, J. Recent Progress on Surface Reconstruction of Earth- Abundant Electrocatalysts for Water Oxidation. Small 2019, 15, 1901980. [CrossRef]

17. Shinagawa, T.; Garcia-Esparza, A.T.; Takanabe, K. Insight on Tafel slopes from a microkinetic analysis of aqueous electrocatalysis for energy conversion. Sci. Rep. 2015, 5, 13801. [CrossRef]

18. Hamann, C.H.; Vielstich, W. Elektrochemie, 4 ed.; Wiley-VCH: Weinheim, Germany, 2005.

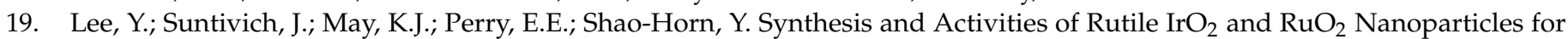
Oxygen Evolution in Acid and Alkaline Solutions. J. Phys. Chem. Lett. 2012, 3, 399-404. [CrossRef] [PubMed]

20. Pi, Y.; Zhang, N.; Guo, S.; Guo, J.; Huang, X. Ultrathin Laminar Ir Superstructure as Highly Efficient Oxygen Evolution Electrocatalyst in Broad pH Range. Nano Lett. 2016, 16, 4424-4430. [CrossRef]

21. Zhao, P.; Hua, X.; Xu, W.; Luo, W.; Chen, S.; Cheng, G. Metal-organic framework-derived hybrid of Fe ${ }_{3} \mathrm{C}$ nanorod-encapsulated, $\mathrm{N}$-doped CNTs on porous carbon sheets for highly efficient oxygen reduction and water oxidation. Catal. Sci. Technol. 2016, 6 , 6365-6371. [CrossRef]

22. Yang, D.; Chen, Y.; Su, Z.; Zhang, X.; Zhang, W.; Srinivas, K. Organic carboxylate-based MOFs and derivatives for electrocatalytic water oxidation. Coord. Chem. Rev. 2021, 428, 213619. [CrossRef]

23. Zhu, Y.P.; Guo, C.; Zheng, Y.; Qiao, S.-Z. Surface and Interface Engineering of Noble-Metal-Free Electrocatalysts for Efficient Energy Conversion Processes. Acc. Chem. Res. 2017, 50, 915-923. [CrossRef] [PubMed]

24. Xiao, Q.; Zhang, Y.; Guo, X.; Jing, L.; Yang, Z.; Xue, Y.; Yan, Y.-M.; Sun, K. A high-performance electrocatalyst for oxygen evolution reactions based on electrochemical post-treatment of ultrathin carbon layer coated cobalt nanoparticles. Chem. Commun. 2014, 50, 13019-13022. [CrossRef] [PubMed]

25. Saha, S.; Ganguli, A.K. FeCoNi Alloy as Noble Metal-Free Electrocatalyst for Oxygen Evolution Reaction (OER). ChemistrySelect 2017, 2, 1630-1636. [CrossRef]

26. Jin, S. How to Effectively Utilize MOFs for Electrocatalysis. ACS Energy Lett. 2019, 4, 1443-1445. [CrossRef]

27. Shao, Q.; Yang, J.; Huang, X. The Design of Water Oxidation Electrocatalysts from Nanoscale Metal-Organic Frameworks. Chem. Eur. J. 2018, 24, 15143-15155. [CrossRef]

28. Janiak, C.; Vieth, J.K. MOFs, MILs and more: Concepts, properties and applications for porous coordination networks (PCNs). New J. Chem. 2010, 34, 2366-2688. [CrossRef]

29. Batten, S.R.; Champness, N.R.; Chen, X.-M.; Garcia-Martinez, J.; Kitagawa, S.; Öhrström, L.; O'Keeffe, M.; Paik Suh, M.; Reedijk, J. Terminology of metal-organic frameworks and coordination polymers (IUPAC Recommendations 2013). Pure Appl. Chem. 2013, 85, 1715-1724. [CrossRef]

30. Aiyappa, H.B.; Masa, J.; Andronescu, C.; Muhler, M.; Fischer, R.A.; Schuhmann, W. MOFs for Electrocatalysis: From Serendipity to Design Strategies. Small Methods 2019, 3, 1800415. [CrossRef]

31. Jiao, L.; Wang, Y.; Jiang, H.-L.; Xu, Q. Metal-Organic Frameworks as Platforms for Catalytic Applications. Adv. Mater. 2018, 30, 1703663. [CrossRef]

32. Wang, H.-F.; Chen, L.; Pang, H.; Kaskel, S.; Xu, Q. MOF-derived electrocatalysts for oxygen reduction, oxygen evolution and hydrogen evolution reactions. Chem. Soc. Rev. 2020, 49, 1414-1448. [CrossRef]

33. Frydendal, R.; Paoli, E.A.; Knudsen, B.P.; Wickman, B.; Malacrida, P.; Stephens, I.E.L.; Chorkendorff, I. Benchmarking the stability of oxygen evolution reaction catalysts: The importance of monitoring mass losses. ChemElectroChem 2014, 1, 2075-2081. [CrossRef] 
34. Özturk, S.; Moon, G.-H.; Spiess, A.; Budiyanto, E.; Roitsch, S.; Tüysüz, H.; Janiak, C. A Highly-Efficient Oxygen Evolution Electrocatalyst Derived from a Metal-Organic Framework and Ketjenblack Carbon Material. ChemPlusChem 2021, 86, 1106-1115. [CrossRef] [PubMed]

35. Li, Z.; Gu, A.; He, X.; Lv, H.; Wang, L.; Lou, Z.; Zhou, Q. Rod bundle-like nickel cobaltate derived from bimetal-organic coordination complex as robust electrocatalyst for oxygen evolution reaction. Solid State Ion. 2019, 331, 37-42. [CrossRef]

36. Jahan, M.; Liu, Z.; Loh, K.P. A Graphene Oxide and Copper-Centered Metal Organic Framework Composite as a Tri-Functional Catalyst for HER, OER, and ORR. Adv. Funct. Mater. 2013, 23, 5363-5372. [CrossRef]

37. Li, J.; Zhou, N.; Song, J.; Fu, L.; Yan, J.; Tang, Y.; Wang, H. Cu-MOF-Derived Cu/ $\mathrm{Cu}_{2} \mathrm{O}$ Nanoparticles and $\mathrm{CuN}_{\mathrm{x}} \mathrm{C}_{\mathrm{y}} \mathrm{Species}$ to Boost Oxygen Reduction Activity of Ketjenblack Carbon in Al-Air Battery. ACS Sustain. Chem. Eng. 2018, 6, 413-421. [CrossRef]

38. Deng, X.; Özturk, S.; Weidenthaler, C.; Tuysuz, H. Iron-Induced Activation of Ordered Mesoporous Nickel Cobalt Oxide Electrocatalyst for the Oxygen Evolution Reaction. ACS Appl. Mater. Interfaces 2017, 9, 21225-21233. [CrossRef]

39. Wang, L.; Wu, Y.; Cao, R.; Ren, L.; Chen, M.; Feng, X.; Zhou, J.; Wang, B. Fe/Ni Metal-Organic Frameworks and Their Binder-Free Thin Films for Efficient Oxygen Evolution with Low Overpotential. ACS Appl. Mater. Interfaces 2016, 8, 16736-16743. [CrossRef]

40. Zheng, F.; Zhang, Z.; Xiang, D.; Li, P.; Du, C.; Zhuang, Z.; Li, X.; Chen, W. Fe/Ni bimetal organic framework as efficient oxygen evolution catalyst with low overpotential. J. Colloid Interface Sci. 2019, 555, 541-547. [CrossRef]

41. Li, D.; Liu, H.; Feng, L. A Review on Advanced FeNi-Based Catalysts for Water Splitting Reaction. Energy Fuels 2020, 34, 13491-13522. [CrossRef]

42. Zhai, Z.-M.; Yang, X.-G.; Yang, Z.-T.; Lu, X.-M.; Ma, L.-F. Trinuclear Ni(II) oriented highly dense packing and $\pi$-conjugation degree of metal-organic frameworks for efficient water oxidation. CrystEngComm 2019, 21, 5862-5866. [CrossRef]

43. Maniam, P.; Stock, N. Investigation of Porous Ni-Based Metal-Organic Frameworks Containing Paddle-Wheel Type Inorganic Building Units via High-Throughput Methods. Inorg. Chem. 2011, 50, 5085-5097. [CrossRef] [PubMed]

44. Furukawa, H.; Go, Y.B.; Ko, N.; Park, Y.K.; Uribe-Romo, F.J.; Kim, J.; O’Keeffe, M.; Yaghi, O.M. Isoreticular Expansion of Metal-Organic Frameworks with Triangular and Square Building Units and the Lowest Calculated Density for Porous Crystals. Inorg. Chem. 2011, 50, 9147-9152. [CrossRef] [PubMed]

45. Forgan, R.S. Modulated self-assembly of metal-organic frameworks. Chem. Sci. 2020, 11, 4546-4562. [CrossRef] [PubMed]

46. Wang, C.; Zhou, M.; Ma, Y.; Tan, H.; Wang, Y.; Li, Y. Hybridized Polyoxometalate-Based Metal-Organic Framework with Ketjenblack for the Nonenzymatic Detection of H2O2. Chem. Asian, J. 2018, 13, 2054-2059. [CrossRef]

47. Ramaraghavulu, R.; Rao, V.K.; Devarayapalli, K.C.; Yoo, K.; Nagajyothi, P.C.; Shim, J. Green synthesized AgNPs decorated on Ketjen black for enhanced catalytic dye degradation. Res. Chem. Intermed. 2021, 47, 637-648. [CrossRef]

48. Li, K.; Liu, Q.; Cheng, H.; Hu, M.; Zhang, S. Classification and carbon structural transformation from anthracite to natural coaly graphite by XRD, Raman spectroscopy, and HRTEM. Spectrochim. Acta Part A 2021, 249, 119286. [CrossRef] [PubMed]

49. Meier, H.; Bienz, S.; Bigler, L.; Fox, T. Spektroskopische Methoden in der Organischen Chemie, 8th ed.; Georg Thieme: Stuttgart, Germany, 2011.

50. Wu, Y.; Song, X.; Li, S.; Zhang, J.; Yang, X.; Shen, P.; Gao, L.; Wei, R.; Zhang, J.; Xiao, G. 3D-monoclinic M-BTC MOF (M = Mn, Co, $\mathrm{Ni}$ ) as highly efficient catalysts for chemical fixation of $\mathrm{CO}_{2}$ into cyclic carbonates. J. Ind. Eng. Chem. 2018, 58, 296-303. [CrossRef]

51. Maruthapandian, V.; Kumaraguru, S.; Mohan, S.; Saraswathy, V.; Muralidharan, S. An Insight on the Electrocatalytic Mechanistic Study of Pristine Ni MOF (BTC) in Alkaline Medium for Enhanced OER and UOR. ChemElectroChem 2018, 5, 2795-2807. [CrossRef]

52. Yaghi, O.M.; Li, H.; Groy, T.L. Construction of Porous Solids from Hydrogen-Bonded Metal Complexes of 1,3,5-Benzenetricarboxylic Acid. J. Am. Chem. Soc. 1996, 118, 9096-9101. [CrossRef]

53. Vuong, G.-T.; Pham, M.-H.; Do, T.-O. Direct synthesis and mechanism of the formation of mixed metal Fe 2 Ni-MIL-88B. CrystEngComm 2013, 15, 9694-9703. [CrossRef]

54. Vu, H.T.; Nguyen, M.B.; Vu, T.M.; Le, G.H.; Pham, T.T.T.; Nguyen, T.D.; Vu, T.A. Synthesis and Application of Novel Nano Fe-BTC/GO Composites as Highly Efficient Photocatalysts in the Dye Degradation. Top. Catal. 2020, 63, 1046-1055. [CrossRef]

55. He, J.; Lu, X.; Yu, J.; Wang, L.; Song, Y. Hierarchical $\mathrm{Co}(\mathrm{OH})_{2}$ nanostructures/glassy carbon electrode derived from $\mathrm{Co}(\mathrm{BTC})$ metal-organic frameworks for glucose sensing. J. Nanopart. Res. 2016, 18, 184. [CrossRef]

56. Gan, Q.; He, H.; Zhao, K.; He, Z.; Liu, S. Morphology-dependent electrochemical performance of Ni-1,3,5-benzenetricarboxylate metal-organic frameworks as an anode material for Li-ion batteries. J. Colloid Interface Sci. 2018, 530, 127-136. [CrossRef] [PubMed]

57. Wang, L.; Ren, L.; Wang, X.; Feng, X.; Zhou, J.; Wang, B. Multivariate MOF-Templated Pomegranate-Like Ni/C as Efficient Bifunctional Electrocatalyst for Hydrogen Evolution and Urea Oxidation. ACS Appl. Mater Interfaces 2018, 10, 4750-4756. [CrossRef]

58. Thommes, M.; Kaneko, K.; Neimark, A.V.; Olivier, J.P.; Rodriguez-Reinoso, F.; Rouquerol, J.; Sing, K.S.W. Physisorption of gases, with special referenceto the evaluation of surface area and pore size distribution (IUPAC Technical Report). Pure Appl. Chem. 2015, 87, 1051-1069. [CrossRef]

59. Wade, C.R.; Dincă, M. Investigation of the synthesis, activation, and isosteric heats of $\mathrm{CO}_{2}$ adsorption of the isostructural series of metal-organic frameworks $\mathrm{M}_{3}(\mathrm{BTC})_{2}(\mathrm{M}=\mathrm{Cr}, \mathrm{Fe}, \mathrm{Ni}, \mathrm{Cu}, \mathrm{Mo}, \mathrm{Ru})$. Dalton Trans. 2012, 41, 7931-7938. [CrossRef]

60. Israr, F.; Chun, D.; Kim, Y.; Kim, D.K. High yield synthesis of Ni-BTC metal-organic framework with ultrasonic irradiation: Role of polar aprotic DMF solvent. Ultrason. Sonochem. 2016, 31, 93-101. [CrossRef]

61. Israr, F.; Kim, D.K.; Kim, Y.; Chun, W. Scope of various solvents and their effects on solvothermal synthesis of Ni-BTC. Quim. Nova 2016, 39, 669-675. [CrossRef] 
62. Long, X.; Ma, Z.; Yu, H.; Gao, X.; Pan, X.; Chen, X.; Yang, S.; Yi, Z. Porous FeNi oxide nanosheets as advanced electrochemical catalysts for sustained water oxidation. J. Mater. Chem. A 2016, 4, 14939-14943. [CrossRef]

63. Wang, Q.; Wei, C.; Li, D.; Guo, W.; Zhong, D.; Zhao, Q. FeNi-based bimetallic MIL-101 directly applicable as an efficient electrocatalyst for oxygen evolution reaction. Microporous Mesoporous Mater. 2019, 286, 92-97. [CrossRef]

64. Louie, M.W.; Bell, A.T. An Investigation of Thin-Film Ni-Fe Oxide Catalysts for the Electrochemical Evolution of Oxygen. J. Am. Chem. Soc. 2013, 135, 12329-12337. [CrossRef] [PubMed]

65. Bates, M.K.; Jia, Q.; Doan, H.; Liang, W.; Mukerjee, S. Charge-Transfer Effects in Ni-Fe and Ni-Fe-Co Mixed-Metal Oxides for the Alkaline Oxygen Evolution Reaction. ACS Catal. 2016, 6, 155-161. [CrossRef]

66. Corrigan, D.A. The Catalysis of the Oxygen Evolution Reaction by Iron Impurities in Thin Film Nickel Oxide Electrodes. J. Electrochem. Soc. 1987, 134, 377-384. [CrossRef]

67. McCrory, C.C.L.; Jung, S.; Peters, J.C.; Jaramillo, T.F. Benchmarking Heterogeneous Electrocatalysts for the Oxygen Evolution Reaction. J. Am. Chem. Soc. 2013, 135, 16977-16987. [CrossRef]

68. McCrory, C.C.L.; Jung, S.; Ferrer, I.M.; Chatman, S.M.; Peters, J.C.; Jaramillo, T.F. Benchmarking Hydrogen Evolving Reaction and Oxygen Evolving Reaction Electrocatalysts for Solar Water Splitting Devices. J. Am. Chem. Soc. 2015, 137, 4347-4357. [CrossRef]

69. Lee, M.; Oh, H.-S.; Cho, M.K.; Ahn, J.-P.; Hwang, Y.J.; Min, B.K. Activation of a Ni electrocatalyst through spontaneous transformation of nickel sulfide to nickel hydroxide in an oxygen evolution reaction. Appl. Catal. B 2018, 233, 130-135. [CrossRef]

70. Möller, S.; Barwe, S.; Masa, J.; Wintrich, D.; Seisel, S.; Baltruschat, H.; Schuhmann, W. Online Monitoring of Electrochemical Carbon Corrosion in Alkaline Electrolytes by Differential Electrochemical Mass Spectrometry. Angew. Chem. Int. Ed. 2020, 59, 1585-1589. [CrossRef]

71. Ji, S.G.; Kim, H.; Lee, W.H.; Oh, H.-S.; Choi, C.H. Real-time monitoring of electrochemical carbon corrosion in alkaline media. J. Mater. Chem. A 2021, 9, 19834-19839. [CrossRef]

72. Li, G.; Anderson, L.; Chen, Y.; Pan, M.; Chuang, P.-Y.A. New insights into evaluation catalyst activity and stability for oxygen evolution reactions in alkaline media. Sustain. Energy Fuels 2018, 2, 237-251. [CrossRef]

73. Krasilshchikov, A.I. Intermediate stages of oxygen anodic evolution. Zhurnal Fiz. Khim. 1963, 37, 531-537.

74. Yuan, Y.F.; Xia, X.H.; Wu, J.B.; Yang, J.L.; Chen, Y.B.; Guo, S.Y. Nickel foam-supported porous $\mathrm{Ni}(\mathrm{OH})_{2} / \mathrm{NiOOH}$ composite film as advanced pseudocapacitor material. Electrochim. Acta 2011, 56, 2627-2632. [CrossRef]

75. Hall, D.S.; Lockwood, D.J.; Bock, C.; MacDougall, B.R. Nickel hydroxides and related materials: A review of their structures, synthesis and properties. Proc. R. Soc. A 2015, 471, 20140792. [CrossRef] [PubMed]

76. Huang, J.; Chen, J.; Yao, T.; He, J.; Jiang, S.; Sun, Z.; Liu, Q.; Cheng, W.; Hu, F.; Jiang, Y.; et al. CoOOH Nanosheets with High Mass Activity for Water Oxidation. Angew. Chem. 2015, 54, 8846-8851. [CrossRef]

77. Hu, J.; Li, S.; Chu, J.; Niu, S.; Wang, J.; Du, Y.; Li, Z.; Han, X.; Xu, P. Understanding the Phase-Induced Electrocatalytic Oxygen Evolution Reaction Activity on FeOOH Nanostructures. ACS Catal. 2019, 9, 10705-10711. [CrossRef]

78. Sivanantham, A.; Ganesan, P.; Vinu, A.; Shanmugam, S. Surface Activation and Reconstruction of Non-Oxide-Based Catalysts Through in Situ Electrochemical Tuning for Oxygen Evolution Reactions in Alkaline Media. ACS Catal. 2020, 10, 463-493. [CrossRef]

79. Zhu, J.; Zhou, G.; Ding, Y.; Wang, Z.; Hu, Y.; Zou, M. A Facile Route to Oriented Nickel Hydroxide Nanocolumns and Porous Nickel Oxide. J. Phys. Chem. C 2007, 111, 5622-5627. [CrossRef]

80. Zheng, W.; Liu, M.; Lee, L.Y.S. Electrochemical Instability of Metal-Organic Frameworks: In Situ Spectroelectrochemical Investigation of the Real Active Sites. ACS. Catal. 2020, 10, 81-92. [CrossRef]

81. Napporn, T.W.; Holade, Y.; Kokoh, B.; Mitsushima, S.; Mayer, K.; Eichberger, B.; Hacker, V. Electrochemical Measurement Methods and Characterization on the Cell Level. In Fuel Cells and Hydrogen: From Fundamentals to Applied Research; Hacker, V., Mitsushima, S., Eds.; Elsevier, B.V.: Amsterdam, The Netherlands, 2018; pp. 175-214. [CrossRef]

82. Pretsch, E.; Bühlmann, P.; Badertscher, M. Spektroskopische Daten Zur Strukturaufklärung Organischer Verbindungen, 5th ed., Springer: Berlin/Heidelberg, Germany, 2010.

83. Young, K.-H.; Wang, L.; Yan, S.; Liao, X.; Meng, T.; Shen, H.; Mays, W.C. Fabrications of High-Capacity Alpha-Ni(OH)2. Batteries 2017, 3, 6. [CrossRef]

84. Lu, C.-T.; Chiu, Y.-W.; Li, M.-J.; Hsueh, K.-L.; Hung, J.-S. Reduction of the Electrode Overpotential of the Oxygen Evolution Reaction by Electrode Surface Modification. Int. J. Electrochem. 2017, 2017, 7494571. [CrossRef] 